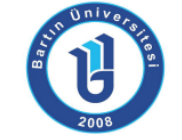

ISSN: 1308-7177

\title{
Oyun Temelli Deneyimlerin Sınıf Ortamı, Öğrencilerin Davranışları, Okul Algıları ve Çatışma Dönüştürme Becerilerine Etkisi
}

Mine Göl-Güven, Yrd. Doç. Dr., Boğaziçi Üniversitesi Eğitim Fakültesi, e-posta, mine.golguven@boun.edu.tr ORCID: http://orcid.org/0000-0002-1675-4478

Öz: Araştırmada erken çocukluk gelişim özelliklerine uygun bir ortamın 'iş̧birliği ve Katııımcılığı Destekleyici Oyun ve Etkinlik Programı (IKDOP)' aracılı̆̆ıyla sağlanmasının etkililiği incelenmiştir. Çalışmanın örneklemini İstanbul iline bağı 14 devlet okulunun 1. sınıfları ve bu sınıfların öğrencileri oluşturmaktadır. IKDOP, 2012-2013 eğitim-öğretim yılının ikinci yarısında toplam 10 hafta, haftada 2 tam gün uygulanmıştır. Araştırmada kontrol grupsuz yarı deneysel yöntem deseni kullanılmıştır. IKDOP'un sınıf ortamı, öğrenci davranışları, öğrencilerin okul algısı ve çatışma dönüştürme becerileri üzerindeki etkisi ön ve son test verileri karşılaştııılarak araştııımışıı. IKDOP'un sınıf ortamı üzerinde istatistiksel anlamda bir fark yaratmadığı fakat olumlu öğrenci davranışlarının artması, olumsuz öğrenci davranışlarının azalmasına katkıda bulunduğu bulgular arasındadır. Bu çalışmayla, çocukların okulda işbirliği ve katılımcılığı destekleyen oyun temelli deneyimler yaşamasının olumlu çıktılarının ileriki çalışmalara kaynak olması umulmaktadır.

Anahtar Kelimeler: oyun, sınıf ortamı, öğrenci davranışları, okul algısı, çatışma dönüştürme becerileri, birinci sınıflar

\section{The Effects of Play-Based Experiences on Classroom Atmosphere, Students' Behaviors, Students' School Perceptions, and Conflict Resolution Skills}

\begin{abstract}
The aim of the study is to investigate the effectiveness of a program titled 'Collaborative and Participatory Play-based Experiences' on classroom atmosphere, students' behaviors, students' school perceptions, and conflict resolution skills. The program was developed to provide an environment that is based on early childhood developmental characteristics. The classrooms and the students of 14 public schools in Istanbul were made up the sample. The program was implemented in the second half of the academic year of 2012-2013 for two full days for 10 weeks. Pre and post test data was collected by using quasi-experimental without the control group method. No statistically significant effect on the classroom atmosphere could be found. However, the program made some improvements with regard to increasing positive students' behaviors and decreasing negative students' behaviors. It is hoped that the positive outcomes of this study could shed light on the future studies that are aimed to provide play-based experiences for children improving collaboration and participation at schools.
\end{abstract}

Key Words: play, classroom atmosphere, student behaviors, school perception, conflict resolution skills, first grades 


\section{GíRiş}

Kendini farklı yollardan ifade etme, arkadaşlık geliştirme, gruba uyum sağlama, kurallara uyma gibi birçok sosyal beceri ve davranışın erken çocukluk döneminde kazanıldığı bilinmektedir. Erken çocukluğa özgü ihtiyaçlara uygun olarak tasarlanan eğitim programlarının ve sınıfın fiziksel yapısı ve günlük akışın, ilkokul eğitiminde mevcut olmadığı görülmektedir. ilkokulun ilk yılında daha çok okuma ve yazma öğretimine verilen ağırlık, çocukların tüm gelişim alanlarını desteklemeye fırsat vermemektedir. Oysaki oyun yoluyla birlikte hareket etme ve işbirliği kurma becerilerinin yanı sıra çocuğun yetişkinin rehberliği ve yol göstericiliği ile fırsatlar yarattığı ve çocuğun kendi topluluğu içinde kendini özgürce ifade edebildiği kültürel ve sanatsal yolların çocuk eğitimi içindeki önemi yadsınamaz. Erken yaşlarda okuma yazma ve matematik gibi akademik becerilerin kazandırımasının ön plana çıkması ve bu becerilerin geleneksel öğretim yöntemleri ile kazandırılmaya çalışılması bazı problemlere yol açmaktadır.

Akademik içeriğin hazırlıksız ve erken yaşlarda verilmesi, bu yapılırken çocukların oyun, dinlenme ve boş zamanlarını değerlendirme gibi yaşıtlarıyla birlikte etkileşim içinde oldukları etkinliklerinin en aza indirilmesi ile sonuçlanmaktadır. Grup içinde yaşanan iletişim ve etkileşimin yerini alan öğretmen odaklı akademik içerik öğretimi, çocuk gelişimi açısından bazı sakıncaları beraberinde getirmektedir. David Elkind akademik baskının gitgide erken yaşlara kadar inmesi ile ilgili endişelerini 'The Hurried Child' kitabı ve takip eden kitaplarında dile getirmiştir (Elkind, 1981, 1987, 2007). Alandaki başka bir isim Lilian Katz akademik çalışmalarını ne kadar erken o kadar iyi olarak adlandırdığı yaklaşımın çocuklara verdiği zararlar üzerine yapılandırmıştır. Erken verilen akademik içeriğin çocuklarda başaramama duygusunu doğurduğu üzerinde durmuştur (Katz, 1988, 2015).

Erken yaşta okul ortamında verilen akademik bilginin olumsuz etkilerinin gösterildiği araştırmaların yanında oyunun gelişimsel faydaları üzerine yapılan araştırmalar yol göstericidir (Bredekamp ve Copple, 2000; Johnson, Christie, Wardle, 2005; NAEYC, 1991, Pellegrini, 2009). Öğretmenlerin günlük akışta ve eğitim programında yer açtığı oyunun, sosyal ve duygusal becerilerin gelişiminde yarattığı olumlu etkilerden bazıları; yardımlaşma, uzlaşma, birlikte hareket etme, duygudaşlık kurma, duyguları anlama ve ifade etmedir (Woolf, 2013). Oyunun; bağımsız düşünebilme, başkalarının düşüncelerini ve niyetlerini anlayabilme, kendi düşüncelerini takip edebilme, dirayetli olma, bir işi başlatma devam ettirme ve bitirme, problem çözme, hayal kurma ve yaratıcılık, karar verme ve öz denetim gibi bilişsel becerilerin gelişmesinde de faydalı olduğu görülmektedir (Ashiabi, 2007; Broadhead, 1997, 2004; Durualp ve Aral, 2010; Miller ve Almon, 2009; Wood ve Attfield, 2005; Woolf, 2013).

Birleşmiş Milletler'in Çocuk Hakları Komitesi (2013) çocuk hakları bildirgesinin 31. maddesi üzerine ele aldığı raporunda, çocukların dinlenme, oyun oynama, boş zamanlarını değerlendirme, kültür, sanat ve spor faaliyetlerine katılma hakkını ele almıştır. Bu raporda eğitim alanındaki baskıdan kaynaklanan oyuna erişimin kısıtlandırılması, çocukların bu haklarının önündeki engellerden biri olarak yer almıştır. Akademik içeriğin ağırlaşması ve yaşa uygunsuzluğu, didaktik öğretim yöntemlerinin kullanımı, yapılandııımış okul aktiviteleri, önceden belirlenmiş günlük akışın esnek olmaması, ev ödevlerinin çokluğu gibi olumsuz özelliklerin çocukları edilgen hale dönüştürdüğü eleştirisi getirilmiştir.

Okulda oyun ile ilgili araştırmalar alanyazında mevcuttur. Sak, Şahin Sak ve Tuncer (2016) anaokuluna giden çocukların ilkokul ile ilgili algılarını araştırdıkları bir çalışmalarında, 30 çocuktan $25^{\prime}$ i ilkokulda okuma-yazma öğrenecekleri, çocukların yarısı oyun oynamaya fırsatları olmayacağı, 6'sı ise oyun oynamak yerine eğitim faaliyetleri yapacakları yönünde tahmin yürütmüşlerdir. Varol (2012) 22 anasınıfı gözleminde, sınıflarda geçirilen zamanın \%23'ünün serbest oyun ve \%5'inin öğretmenin yönetiminde oynanan yapılandırılmış oyun olduğunu 
ortaya koymuştur. Akademik içerikli çalışmalar (okuma-yazmaya hazırlık, dil, matematik ve bilim etkinlikleri) \%12'lik bir zamanı kapsamaktadır. Bu çalışmada gün içinde oyuna akademik çalışmalardan daha fazla yer ayrıldığı görülse de, Gülay Ogelman (2014) çalışmasında, 44 okul öncesi sınıfı gözlem sonuçlarına göre serbest zaman sırasında öğretmenlerin \%40'ının sınıfta başka işlerle ilgilendikleri, \%16'sının vakitlerini sınıf dışında geçirdiklerini tespit etmiştir. Tuğrul v.d. (2014) anaokuluna devam eden 89 çocukla yaptıkları görüşmelerde, çocukların sadece \%1'i öğretmenleri ile oyun oynadıklarını belirtmiştir. Böyle bir durumda, yetişkinin rehberliği ile oyun esnasında çeşitli becerilerin geliştirilmesi fırsatlarının sınırlı olabileceği düşünülebilir.

Oyun ya akademi ve öğrenmenin dışında bırakılmış ya da son derece kısıtlı ve sınırlı zaman ve mekanların içine sıkıştırıımıştır. Tuğrul v.d. (2014) çalışmasında, çocukların oyun ve iş kavramlarını ayrı tuttukları, okulda resim yapma, yazı yazma, kitap okuma gibi etkinlikleri iş kapsamına aldıklarını ortaya çıkarmıştır. Benzer ayrımı öğretmenlerin de yaptıkları, günlük program içindeki Türkçe, dil, sanat, müzik, fen ve doğa etkinliklerinden sonra oyun oynandığı belirttikleri sonuçlar arasında yer almıştır. Çocuklara oyun oynamadıkları zamanda ne yaptıkları sorulduğunda cevaplarının \%64'ünün evde televizyon seyrederim, cevaplarının \%45'inin okulda resim-boyama yaparım olduğu görülmüştür.

Walsh v.d. (2011) oyun zamanı ve yapılandırılmış etkinliklerden oluşan ve öğretmenin yönettiği ders zamanı olarak yapılan ayrımı yüzeysel bulmaktadır. Bunun yerine oyun yapısının (Eng. playful structure) öğretmen-öğrenci etkileşiminde bir yaklaşım olarak benimsenmesi ve tüm derslerde bu yaklaşımın kullanılması gerektiğini önermiştir. Öğretmenler ise önerilen bu yapı içindeki rollerini kestiremedikleri, hem ders anlatıp hem oyuncu rollerini sergilemekte zorlandıklarını belirtmiştir. Aynı zamanda öğretmenler, oyunculuğun sınıftaki otoriterini sarsmasından endişelendiklerini ifade etmiştir. Türkiye'de yapılan çalışmalar da öğretmenlerin oyun davranışları ve algılarını ortaya koymaktadır. Örneğin öğretmenler, serbest oyun esnasında ancak çatışma çıktığında müdahale ederek (Varol, 2012) veya günlük işlerini yaparak müdahil olmayan bir rol üstlenmektedir (Aras, 2016). Öğretmenler oyunun önemi konusunda fikir beyan etseler de oyuna katılma yönünde inisiyatif almamaları (Aras, 2016; Tuğrul vd., 2014), çocukların da öğretmenlerini oyuna katma yönünde beklentilerinin olmaması (Koçyiğit ve Başara Baydilek, 2015) oyunun eğitim kurumlarındaki yerinin ne denli dar olduğunun göstergesidir. Başka bir gösterge ise okulda oynanan oyunun sadece spor veya fiziksel etkinlik kapsamında değerlendirimesidir. Güven ve Yıldız (2014), 12 ilkokul öğretmeninin oyun ve fiziksel etkinlikler saati ile ilgili görüşlerini almıştır. Öğretmenler bu saatlerin aktif olabilmesi için spor salonlarının yeterli ve kaliteli olmasından, araç gereçlerle donatılmasından bahsetmişler, bu dersin branş öğretmenleri tarafından verilmesi gerektiğini, sınıf öğretmenlerinin ise bu konuda bilgi ve becerilerinin yeterli olmadığını ve eğitime ihtiyaç duyulduğunu belitmiştir.

Oyunun kendiliğinden başlama, özgür olma, sonucun değil sürecin önemli olması gibi çocuğun doğasından gelen bir güdü olduğu yönünde fikirlerin yanısıra (Gray, 2013), oyun temelli öğrenme veya oyun aracılığıyla öğrenme gibi oyunun eğitsel yönüne ağırlık veren görüşler mevcuttur (Pramling Samuelsson ve Johansson, 2006). Oyunun akademik becerilerin kazandırılmasında bir yöntem olarak görülmesi bakış açısından yola çıkılarak yapılan birçok çalışma vardır. Örneğin Einarsdottir (2014), okuma yazma hazırlığı ile ilgili yapılan çalışmaların oyun yoluyla desteklenmesi, yine Ginsburg'ün (2006) benzer çalışmasında oyunun matematik eğitiminde kullanılması ile ilgili olumlu çıktılar paylaşılmıştır. Oyunun, öğretmeyi ve sıkıcı konuları eğlenceli, cazip ve çekici hale dönüştüren bir eğitim aracı olarak okula girmesi ve öğrenmeye hayat vermesi umulmaktadır (Bulunuz, 2012).

Yukarıda yer verilen çalışmalardan da anlaşılacağı üzere okullarda akademik becerilerin kazandırılmasına ağırlık verilmesi ve öğretmenlerin oyuna katılımının sınırlı olması, oyun 
yoluyla çocukların sosyal-duygusal becerilerini geliştirmeye yönelik uygulamaların sınırlı olmasına yol açmaktadır. Başka bir zorluk ise öğretmenlerin oyunun değeri, eğitsel yönü ve oyundaki rolleri ile ilgili net olmamalarından kaynaklanmaktadır. Alanyazında sınırlıık ve zorluklardan bahsedilmekle birlikte, oyunun sosyo-duygusal gelişim üzerine olumlu etkisi ağırlıklı olarak araştırılmaktadır (Broadhead, 2004). Durualp ve Aral (2010) sosyal beceri edinimini destekleyen 8 haftalık oyun temelli bir programın olumlu çıktılarını paylaşmıştır. Uygulanan program sonucunda deney grubundaki çocukların dinleme, paylaşma, yardımlaşma, duyguları anlama ve ifade etme, yardım isteme ve yardım önerme ve problem çözme gibi bir çok sosyal beceride kontrol grubundaki çocuklara göre ilerleme kaydettikleri ortaya çıkmıştır. Woolf (2013) bir ilkokulda haftalık uygulanan oyun yoluyla sosyo-duygusal beceri geliştirme programının, özdenetim, duygudaşlık, duygu özellikle öfke kontrolü, ilişkilerde karşlıklılık ve genel anlamda sosyal beceri geliştirme yönündeki olumlu çıktılarından bahsetmiştir. Martlew v.d. (2014) çalışmasında, oyun temelli pedagoji yoluyla aktif öğrenme uygulamalarında bulundukları belirlenen 6 sını öğretmeninin uygulamaları takip edildiğinde, çocuk merkezli çalışmalara ve akran etkileşimine rastlanmamıştır. Bu çalışmada, öğretmenlerin oyun yoluyla aktif öğrenme ile ilgili farklı görüşlerinin olmasının bu sonucu doğurduğundan bahsedilmiştir. Oyunun sosyal becerilerin gelişimine katkısının araştırmalarla desteklenmesinin uygulamalara yansıması umulmaktadır.

Bu araştırmanın amacı ilkokul 1. sınıf öğrencilerinin işbirlikçi ve katılımcılığı destekleyici oyun ve ortak etkinlikler yoluyla sosyal becerilerini geliştirmek üzere planlanan ve uygulanan programın etkililiğini araştırmaktır. İşbirliği ve Katılımcılığı Destekleyici Oyun ve Etkinlik Programının (iKDOP) iki odak noktası mevcuttur. IKDOP, sınıf yönetimi ve çocuk davranışlarını anlama ve rehberlik etme tekniklerine yer vermektedir. Program aynı zamanda işbirliği ve yaratıcılığı destekleyen oyun ve etkinlikleri içermektedir. Bu yolla, öğrencilerin sınıf ortamına, öğretmen ve arkadaşlarına uyum gösterme konusunda karşılaşabilecekleri problemleri en aza indirilebileceği düşünülmektir.

\section{İşbirliği ve Katılımcılığı Destekleyici Oyun ve Etkinlikler Programı (IKDOP)}

Araştırma aşamasında önceden hazırlanmış bir programın uygulanması yerine, bağlamda anlamı olan, ihtiyaçların belirlendiği ve bu ihtiyaçların giderilmeye çalışıldığı bir program geliştirilmesi hedeflenmiştir. Bu nedenle, iki haftayı kapsayan, öğretmen ve yöneticilerle yapılan görüşmeler ve gözlemlerin sonuçlarına bakıldığında, sınıflarda en çok çocuk davranışlarını anlama ve rehberlik etme ve sınıf yönetimi konularında zorluk yaşandığı görülmüştür. Ayrıca, çocukların çatışma çözümü yerine kavga ve tartışmaya yöneldikleri saptanmıştır. Bunlara ek olarak Milli Eğitim müfredatında bulunan oyun ve fiziksel aktivite saatinin verimli kullanılmadığı bu saatlerin daha çok akademik becerileri geliştirme, özellikle okuma-yazma öğretimi amacıyla kullanıldığı gözlemlenmiştir.

Programın iki odak noktası mevcuttur. IKDOP, sınıf yönetimi ve çocuk davranışlarını anlama ve rehberlik etme tekniklerine yer vermektedir. Program aynı zamanda işbirliği ve yaratıcılığı destekleyen oyun ve etkinlikleri içermektedir. Programın genel amacı, sınıfın fiziksel ve sosyal/ilişkisel ortamını sınıf yönetimi ilke ve prensiplerine uygun şekilde gözden geçirmektir. Bu yolla olumlu sınıf atmosferi ve kültürü oluşturulması hedeflenmektedir. Programda sınıf içinde sosyal ve duygusal beceri gelişiminde desteklenen çocukların oyun ve fiziksel etkinlikler saati çerçevesinde birlikte hareket etme, grup oluşturma, işbirliğine önem verme davranışlarını destekleyici oyun ve etkinlikler sunulmaktadır.

Programın geliştirilme sürecine alanyazın taraması ile başlanmıştır. Erken çocukluk döneminin gelişimsel özellikleri dikkate alınarak her haftaya bir deneyim sunulmak üzere program tasarlanmıştır. Programın yanısıra sınıf düzenlemesi ile ilgili bir takım görseller 
hazırlanmıştır. Bu görseller sınıf yönetimini kolaylaştırıcı ve destekleyici özelliklere sahiptir. Örneğin kurallar panosu, yoklama tablosu, günlük akış görseli, sorumluluk panosu vs. gibi. Bu görseller kullanılarak öğrencilerden beklenen olumlu davranışların tanıtımı ve pekiştirilmesi sağlanmaya çalışıımıştır. Bunun haricinde program uygulayıcılar, olumsuz davranışı gözardı etme, sinyal gönderme, uzaklık ayarı, farklı gruplandırmalarla öğrencilerin aktif katılımını sağlama, olumlu davranışın sözel ve sözel olmayan yollarla pekiştirilmesi, uygun şekillerde yönerge verme gibi teknikler kullanarak sınıf süreçlerinin olumlu bir şekilde yönetilmesine sağlamışlardır.

Sürece yayılan olumlu sınıf ortamı oluşturma çabalarının yanı sıra, öğrencilerle haftanın iki günü, günde bir saat Oyun ve Fiziksel Etkinlikler Saatinde iKDOP programında yer alan deneyimler sunulmuştur. Bu deneyimlerin beş temel özelliği vardır: (1) Katılımcllık: Herkes katııır ve oyundan atılan ya da dışlanan kişi olmaz. Oyunlarda kaybetmek yoktur. (2) iletişim: Sözel ya da sözsüz iletişim, aktif dinleme, karar verme ve tartışma içerir. (3) İ̧̧birliği: Grubun amacına ulaşması için herkesin karşılıklı aktif katılımı gerekir. Grupla birlikte belirlenen, karar verilen belirli bir amaca ulaşmak için herkesin bir görevinin olduğu katılımc bir süreçtir. (4) Kurgu: "Mış gibi" oyunları içerir. "Şimdi kendimizi bir ormanda farz edelim, bir karınca olduğumuzu düşünelim" gibi. (5) Eğlence: Amacın en büyük parçasıdır. Çocukları eğlence yoluyla arkadaşça grupla birlikte hareket etmeye teşvik eder. Bu özellikler çocuklarla her oyun saatinden önce kurallar ve beklentilerle birlikte paylaşılır.

Oyun saati üç bölüme ayrılmıştır: Giriş, Gelişme, Kapanış. Giriş bölümü 5 ile 10 dakika sürer, çembere oturulur ve oyun amaçları hakkında konuşulur. Gelişme bölümü ise bir ya da iki oyunun oynandığı süreçtir. Kapanış 10 dakika sürer. Oyuncuların yaşadığı olumlu süreyi, karşılaştıkları ve çözdükleri problem durumlarını yansıtııları süreçtir. Lider oynanan oyunları sorar, kendi gözlemlerini aktarır. İşbirlikçi yaratıcı oyunların getirdiği duygular hakkında konuşulur. Olumlu atmosfer yaratması ve yapılandırıcı gözlemleri aktarması önemlidir. "Grupta yaşanan olayda Ayşe'nin paylaşmak için sırayla kullanalım dediğini duydum" ya da "Bu noktada farklı bir fikir ürettiniz" vb. Kapanış şarkısı söylenip oyun saati sonlandırılır.

Grup liderlerinin, çocukları destekleyici ve yüreklendirici olması, sonuca değil sürece ve çabaya önem verildiğini vurgulaması, hatalar karşııında affedici olunmasını özendirmesi, güler yüzlü, olumlu bakış açısına sahip ve çocukların kolayca yaklaşabileceği bir yetişkin modeli olması gerekmektedir. Çocukların yeni fikirler üretmesi, ve bu fikirleri denemeleri özendirilmektedir. Gruptaki herkesin fikirlerine, yaptığı yaratıcı katkıya ve katılımına önem vererek işbirliğini ve katılımı sağlanması önemlidir. Çocukların problemlerini onlar namına çözmek yerine, çocuklara fırsat vererek çözüm üretmelerini kolaylaştırmak, çatışmalarda tarafların duygularını öğrenmek ve herkesin kabul edebileceği çözümler üretmelerinde onlara yardımcı olmak grup liderlerinin uygulamalarında önem verdikleri noktalardır.

\section{YÖNTEM}

\section{1. Çalışma Grubu}

Yoksun ve yoksul mahallelerde eğitim hizmeti veren 14 okul çalışmaya katılmıştır. On dört okulun her birinde bir adet 1. sınıf rastlantısal bir şekilde seçilmiştir. Uygulama ve veri toplama bu sınıflarda gerçekleştirilmiştir. Sınıflarda bulunan öğrenci sayısı 403' tür. Bu öğrencilerin 203'ü $(\% 50,4)$ kız, $200 \quad(49,6 \%)$ öğrenci erkektir. Öğrencilerin \%39,5'unun okulöncesi deneyimi varken, \%47,1'i herhangi bir okulöncesi kurumuna devam etmemiştir

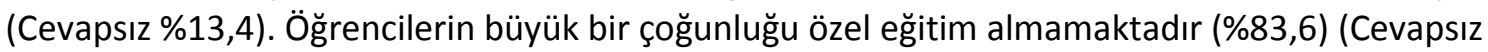
14,6). \%84,6'sı okula devam etmektedir (Cevapsız \%10,4). Öğrencilerin \%33,8'i 66 ay ve 66 aydan daha küçüktür. 67-72 ay arası öğrencilerin yüzdesi ise $31,8^{\prime}$ dir. 73-78 ay arası öğrenciler grubun $\% 22,6$ 'sını oluşturmaktadır. \%11,8 ise 79 ay ve üstüdür. 


\section{2. İşlem}

Program uygulaması 28 Okul Öncesi Öğretmenliği Programı lisans öğrencisi (grup liderleri) tarafından yürütülmüştür. Grup liderleri ilk iki hafta okul ziyaretlerinde sınıfları tanımaya çalışmışlar, gözlem ve görüşmeler yoluyla ihtiyaçları belirlemişlerdir. IKDOP, sınıfların ihtiyaçlarına cevap verecek şekilde geliştirilmiştir. Program uygulama, 2012-2013 eğitimöğretim yılının ikinci yarısında toplam 10 hafta, haftada 2 tam gün yapılmıştır. Grup liderleri, hem öğretmen ve çocukların gün içerisinde ihtiyaç duydukları desteği vermeye çalışmışlar hem de özellikle oyun ve etkinlik saatinde geliştirilen programı uygulamışlardır. Gün içinde ise öğrencilerin birlikte çalışma, problem çözme, çatışma yönetimi gibi becerileri desteklenmeye çalışılmıştır. Ayrıca sınıflar, davranış yönetimi, rutin, kural ve beklenti oluşturmaya yardımcı görsellerle desteklenmeye çalışılmıştır.

2013 yılı Mart ayı başında ön test Mayıs ayı sonunda ise son test verileri toplanmıştır. Yedi yüksek lisans öğrencisi okullara yaptıkları bu ziyaretlerde, gözlemlerde kullanılmak üzere ölçekler ve görüşme formları kullanılarak veri toplamıştır. Öğrencilere verilen eğitimde, ölçeklerdeki her bir gösterge tek tek konuşulup, örneklendirilip, gözlemcilerin ortak anlam çıkarımı ve mutabakatı sağlanmıştır. Toplamda 14 sınıf, öğrenciler tarafından tüm günü kapsayan gözlemlere tabi tutulmuş ve gözlemler hem anekdot olarak hem de puanlandırma sistemiyle kayıt altına alınmıştır. Sınıfın fiziksel ve sosyal durumu ve öğrenci davranışları gözlemleri yapılmıştır. Öğrencilerle okul algısı ve çatışma dönüştürme becerilerini saptamak amacıyla görüşmeler yapılmıştır. Sınıf gözlemleri, Sınıf Ortamı Gözlem Ölçeği ve Öğrenci Davranışları Gözlem Ölçeği kullanılarak yapılmıştır. Okul Algısı Ölçeği ve Çatışma Dönüştürme Beceriler Ölçeği çocuklarla yapılan görüşmelerde kullanılmıştır. Ölçeklerin uyarlama çalışması Türkçe'ye çevirisi ve geri çevirisi yapılmıştır. İki eğitimci tarafından içerik geçerlilikleri çalışılmıştır. Tüm ölçeklerin iteme bağlı sıklık, yüzdelik, ortalama ve standart sapma hesaplamaları yapılmıştır. Ön ve son test verilerinin analizinde eşleştirmeli t test analizi kullanılmıştır.

Ön ve son test verilerini toplamak üzere yapılan sınıf ziyaretlerinde ilk yapılan çalışma, Sınıf Ortamı Ölçeği'ni kullanarak yapılan gözlemler olmuştur. Yaklaşık 2 saat süreyle sınıf ortamı gözlemini takip eden 1 ders saati süresince olumlu ve olumsuz öğrenci davranışlarına odaklanılan Öğrenci Davranışları Gözlem Ölçeği kullanılmıştır. Burada çocukların kendiliğinden oluşturdukları gruplar (örn., teneffüste oyun oynayan grup gibi) veya öğretmen veya ziyaretçi tarafından oluşturulan 3-5 kişilik rastlantısal gruplardan biri gözlemlenmiştir. 10 dakika gözlem yapıldıktan sonra 5 dakika not tutulan seanslar her sınıf için 3 defa tekrar etmiştir. Ön testte 42 gözlem (14 sınıf $X 3$ gözlem) son testte 32 gözlem $^{1}$ verisi mevcuttur.

Ardından rastlantısal olarak seçilen bu grup üyeleri ile Okul Algısı ve Çatışma Dönüştürme Beceriler ölçekleri kullanılarak bire bir görüşmeler yapılmıştır. Okul Algısı Ölçeği'ni kullanarak yapılan görüşmelerde ön testte 50 , son testte 45 çocuk ile bir araya gelinmiştir. Bu çocuklardan 30 çocuğun hem ön hem de son test verileri mevcuttur. Çatışma Dönüştürme Beceriler Ölçeği ise ön testte 25 , son testte ise 45 çocukla uygulanmıştır. Bu çocuklardan ise sadece 14 çocuğun hem ön hem de son test verileri vardır.

\subsubsection{Sınıf Ortamı Gözlem Ölçeği}

Öncelikle sınıfların genel durumu ile ilgili veri toplanmıştır. Dört farklı alt ölçekten oluşan bu ölçme aracı sınıfın genel durumunu ortaya koyma amacıyla Golly ve Snead (2004)

\footnotetext{
${ }^{1}$ iki okul son değerlendirmeye katılmamıştır. Birinde sınıf öğretmeni rahatsızlanıp rapor almıştır. Diğer okulda öğretmen veri toplanması için uygun gün ve saat ayarlayamamıştır.
} 
tarafından geliştirilmiştir. Ölçeğin Türkçeye uyarlaması yapılmıştır. Bu ölçeğin amacı bir sınıf için gerekli olan düzenli, olumlu ve çocuklar tarafından katılımı arttıran ana öğeleri değerlendirmektir. Ölçeğin 4 ana öğesi bulunmaktadır: (1) Fiziksel ortam, (2) Sınıf organizasyonu, (3) Sınıf yönetimi, (4) Sosyal atmosfer. Illk alt başlık sınıfın fiziksel açıdan düzenlenmesidir. Sınıfın temizliği ve düzeni, sınıftaki mobilyaların çocuk boyutlarında olup olmaması, sınıftaki materyallerin sağlamlığı ve sayıca yeterliliği, sınıftaki trafik akışı, alan kullanımı gibi konuları içeren 13 maddeden oluşmaktadır. Sınıf organizasyonu alt başlığında ise günlük akışın mevcut olması ve bu akışın bir düzene bağlı olması, öğrenciler ve öğretmenlerin kolayca görebileceği bir yerde ve beklentilere uygun bir şekilde ifade edilmiş olması, kurallar ve beklentilerin öğrenciler ve öğretmenler tarafından birlikte oluşturulmuş olması, farklı intiyaçlara göre görselleştirilmesi, öğrencilerin kullanımına açık bir şekilde oluşturulmuş sorumluluk panosu, yoklama çizelgesi gibi görsellerin mevcut olması gibi 7 madde mevcuttur. Burada önemli olan öğretmenlerin sınıf içindeki düzenini öğrencilerle birlikte oluşturması ve düzene uyumu öğretmen kontrolünden çıkartıp, öğrenci denetimine bırakmasıdır. Sınıf yönetimi tekniklerini ölçen 31 madde mevcuttur. Bu alt başlıkta öğretmen ve çocuklar arasındaki iletişim ve etkileşim, öğretmenin pekiştireç, geri bildirim ve ödül kullanımı, öğrencilerin ve öğretmenlerin birlikte problem çözme yöntemleri, öğretmenlerin kurallar ve beklentileri öğrencileriyle paylaşım şekilleri, dersler ve ders içindeki aktiviteler arası geçişler ve çocukların gözlemlenmesi ve rehberlik edilmesi konuları içerilmiştir. Sınıftaki sosyal atmosfer alt başığını ölçen 26 madde, öğretmenler arası etkileşim, öğretmenlerin öğrencilerle etkileşimi, öğrencilerin birbirleriyle etkileşimi ve öğretmenlerin çocuklara verdiği davranış yönetimiyle ilgili desteği içermektedir. Ölçekteki her bir gösterge, Güçlü (3), Orta (2) ve Zayıf (1) olmak üzere puanlandırılmıştır. Ölçekten alınabilecek en düşük puan 77, en yüksek puan 231'dir.

\subsection{2. Öğrenci Davranışları Gözlem Ölçeği}

'Observational Checklists for Prosocial Behaviors of Elementary School Childen' ('Observational Checklist', n.d.), ölçeğinden yararlanılarak oluşturulmuştur. Bu ölçekte 10 olumlu ve 10 olumsuz davranış yer almaktadır. Olumlu davranışlardan bazıları, yardımseverlik, işbirliği, liderlik ve problem çözme ve karar vermedir. Olumsuz davranışlardan bazıları ise, kayıtsızlık ve soğuk davranma, patronluk taslama ve zorbalık, aşağılama ve isim takma ve sorumluluk, iş ve karar vermekten kaçınmadır. Sınıf içi gözlemlerde 10 dakika gözlem yapmak, 5 dakika gözlem notlarını forma yazmak ve gözlemlenen davranışların sıklıklarını forma geçirmek üzere 3 adet gözlem yapılmıştır. Her bir gözlem için odak grup rastlantısal örneklem alma yöntemiyle belirlenmiştir. Sınıfta veya okul bahçesinde grup halinde oyun oynayan veya ders esnasında yine grup halinde öğretmenlerinin verdiği bir görev veya ödev üzerinde çalışan öğrencileri gözlemlenmiştir. Okul tipi, gözlem yapılan sınıfın eğitim kademesi, sınıf mevcudu (Kız/Erkek) ve her bir gözlem için seçilen odak grubunun mevcudu (Kız/Erkek) not alınmıştır. Bu gözlemlerin ortalamaları alınarak her bir sınıf için davranışların gözlemlenme sıklık hesaplamaları yapılmıştır.

\subsubsection{Okul Algısı Ölçeği}

Odak grupta davranışları gözlemlenen çocuklar bire bir görüşmelere davet edilmiştir. $\mathrm{Bu}$ davetlerde isteksiz olan çocuklar çalışmaya katılmamıştır. Daveti kabul eden çocuklara "Sana okulunla ilgili birkaç soru soracağım. Verdiğin cevaplar sadece bende kalacak, kimseyle paylaşmayacağım. İstediğin yerde beni durdurup sorularıma cevap vermek istemediğini söyleyebilirsin. Devam etmek ister misin?" şeklinde tanıtıc bir konuşma yapılmıştır. Devam etmek isteyen çocuklara Okul Algısı Ölçeği'nin yönergesi verilmiştir.

Gelişim Araştırmaları Merkezi'nin Çocuk Gelişimi Projesi için geliştirilen Öğrenci Anketi'nin, Okul Sevgisi, Sınıf Dayanışması, Öğretmene Saygı ve Güven Duyma, Öğrenci 
Otonomisi ve Öğrencilerin Sınıf içi Prosedürlere Etki Güçleri, Özgüven ve Akademik Özgüven alt ölçekleri kullanılmıştır ('Child Development Project' 1988-2005). Ölçek toplamda 25 maddeden oluşmaktadır. Bu maddelerden 10 tanesi olumsuz ifade ve anlamlar taşımaktadır. Okullarıyla ilgili farklı öğelerin algılanışı çocukların gözünden irdelemeye çalışan bir ölçektir. Ölçekte Okul Sevgisi alt ölçeği 4 madde (örn., Okulunu seviyor musun?), Sınıf Dayanışması 4 madde (örn., Sınıfta birbirinize yardım eder misiniz?), Öğretmene Saygı ve Güven Duyma 6 madde (örn., Öğretmenin verdiği sözü tutar mı?), Öğrenci Otonomisi ve Öğrencilerin Sınıf içi Prosedürlere Etki Güçleri 5 madde (örn., Öğretmeniniz bazı kararlar alırken sizin fikrinizi sorar mı?), Özgüven 2 madde (örn., Kendini olduğun gibi seviyor musun?) ve Akademik Özgüven 4 maddeden (örn., Başarılı bir öğrenci misin?) oluşmaktadır. Çocuklara verilen cevap anahtarında uygun olan yüzü parmakları ile göstererek cevap vermeleri istenmiştir. Gülen yüz (evet), somurtkan yüz (hayır) ve ifadesiz yüz (bazen) seçeneklerinden birini tercih etmeleri istenmiştir. Bazı çocuklar bu yüzleri kullanmayarak evet, hayır veya bazen seçeneklerini sözlü olarak ifade etmiştir.

\subsection{4. Çatışma Dönüştürme Beceriler Ölçeği}

Çatışma durumlarıyla karşı karşıya kalan çocukların çözüm yollarından birini seçmesi üzerine geliştirilmiş bir ölçektir. Bu çalışmada kullanılmak üzere, Gelişim Araştırmaları Merkezi'nin Çocuk Gelişimi Projesi için geliştirilen Öğrenci Anketi'nin Çatışma Dönüştürme Becerileriler isimli alt ölçeğinin çevirisi yapılmıştır ('Child Development Project' 1988-2005). Ölçekte 6 adet kişiler arası çatışma içeren durum mevcuttur. Örneğin "Kalemini bir anlığına sırana bıraktığını düşün. Sınıfından bir çocuk gelip onu alıyor. Ondan kalemini geri vermesini istiyorsun, ancak o "hayır" diyor. Bu durumda ne yaparsın?". Çocuktan verilen 5 seçenekten birini seçmesi istenir. Bu seçenekler her durum için farklılık göstermektedir: A. Kalemi onun elinden çekip alırsın, B. Çalışmanı bitirmek için o kaleme gerçekten ihtiyacın olduğunu söylersin, C. Öğretmeninden kalemini geri verdirmesini istersin, D. Başka bir kalem bulmasında ona yardım edersin ya da ona sen işini bitirdikten sonra kalemini kullanabileceğini söylersin, $E$. Eğer kalemini geri vermezse onu döveceğini ya da senin de onun bir şeyini alacağını söylersin. Çocuğun çözüm alternatiflerini değerlendirmesini sağlamak için bir kez "Eğer yaptığın şey işe yaramazsa ne yaparsın?" şeklinde soru yöneltilir. Bir seçenek değiştirilerek aynı seçenekler sunulur ("Çalışmanı bitirmek için o kaleme gerçekten ihtiyacın olduğunu söylersin." yerine "Kendine başka bir kalem bulursun." gibi). Seçenekler 4 farklı çözüm yolunu işaret etmektedir: Uzlaşmacı, Saldırgan (fiziksel veya ilişkisel), Yetişkin Odaklı ve Çekimser. Her bir soru için seçilen uzlaşmacı, saldırgan, yetişkin odaklı ve çekimser kategorilerine ait cevaplar sayılarak her bir çocuğun bu dört kategoriye ait puanı hesaplanmıştır.

\subsection{Verilerin Analizi}

Okullardan toplanan tüm veriler Microsft Word@ ve SPSSC programları kullanılarak elektronik hale dönüştürülmüştür. Sınıf Ortamı Gözlem Ölçeği, Öğrenci Davranışları Gözlem Ölçeği, Okul Algısı Ölçeği ve Çatışma Dönüştürme Becerileri Ölçeği kullanılarak sınıf bazında elde edilen veriler her bir sınıfın profilini çıkartabilmek amacıyla kullanılmıştır. Okullardan edinilen öğrenci listelerinden ve sınıf öğretmenlerinden alınan bilgilere göre sınıf ve öğrencilerle ilgili bilgilere ulaşılmıştır. Sınıf mevcudu, yaş, cinsiyet, çocukların okulöncesi deneyimleri, özel eğitim alma ve devamsızlık durumları bilgileri sıklık (n) ve yüzdelik (\%) hesaplamaları yapılmıştır. Sınıf Ortamı Gözlem, Öğrenci Davranışları Gözlem, Okul Algısı ve Çatışma Dönüştürme Becerileri ölçeklerinin ön ve son test verilerinin iteme bağlı sıklık, yüzdelik, ortalama ve standart sapma hesaplamaları yapılmıştır.

Sınıf Ortamı Ölçeğinin 4 adet alt ölçeğinin ortalama ve standart sapmaları hesaplanmıştır. Ön ve son test verilerinin analizinde eşleştirmeli t test analizi kullanılmıştır. Öğrenci Davranışları Gözlem Ölçeği kullanılarak olumlu ve olumsuz davranış olmak üzere iki 
ayrı form oluşturulmuş ve bu ıskalarının gözlemleme sıklıklarının ortalama ve standart sapmaları puanları hesaplanmıştır. Ön ve son test verilerinin analizinde eşleştirmeli $t$ test analizi kullanılmıştır. Okul Algısı Ölçeği'nde olumsuz ifadeler ters kodlamalar yapılarak ölçeğin olumlu okul algısını tespit etmesi sağlanmıştır. Daha sonra öğrencilerin verdikleri cevapların yine iteme bağlı sıklık ve ortalama hesaplamaları yapılmıştır. Ön ve son test verilerinin analizinde iteme bağı ışleştirmeli $t$ test analizi kullanılmıştır. Çatışma Dönüştürme Becerileri Ölçeği'ndeki cevaplar ise yüzde hesaplamaları yapılmış, ön ve son test arasındaki yüzdelik farklar hesaplanmıştır².

\section{BULGULAR}

Sınıf Ortamı Gözlem Ölçeğinin ön ve son test ortalamalarına bakıldığında hemen hemen tüm alt ölçeklerde son test verilerinin ön test verilerine göre daha yüksek değerler aldığı görülmektedir. Sınıflardaki görsellerin farklı ilgi, yetenek ve kültürlere göre ilk verilere kıyasla farklılaştığı gözlemlenmiştir $(\bar{X} 1=5.92 ; \bar{X} 2=6.91)$. Yine günlük akış $(\bar{X} 1=3.16 ; \bar{X} 2=3.25)$, kurallar ve beklentiler $(\bar{X} 1=2.08 ; \bar{X} 2=2.66)$ gibi sınıfın yönetimsel organizasyonu ile ilgili yaklaşımlarda olumlu yönde bir artış olduğu görülmektedir. Öğretmen ve çocuklar arasındaki etkileşim ( $\bar{X} 1=11.85 ; \bar{X} 2=12.18)$, pekiştireç, geri bildirim ve ödül kullanımı $(\bar{X} 1=8.42 ; \bar{X} 2=8.54)$, çocuk ve yetişkinlerin birlikte problem çözmeleri $(\bar{X} 1=8.71 ; \bar{X} 2=10.54)$ ve geçişler $(\bar{X} 1=11.57 ; \bar{X} 2=12.60)$ olarak gözlemlenmiştir. Son olarak çocukların birbirleriyle olan etkileşimleri ( $\bar{X} 1=17.07$; $\bar{X} 2=17.45)$ ve öğretmenin çocuklara verdiği destekte $(\bar{X} 1=8.14, \bar{X} 2=10.66)$ olumlu yönde artış görülmüştür. Fakat bu farkların hiçbiri istatistiksel anlamlılık derecesine ulaşmamıştır (Tablo 1).

Tablo 1

Sınıf Ortamı Gözlem Ön ve Son Test Ortalama, Standart Sapma ve t Test Değerleri

\begin{tabular}{|c|c|c|c|c|c|}
\hline & Ön test & & Son test & & \\
\hline Sınıf Ortamı & $\overline{\boldsymbol{X}}$ & SS & $\overline{\boldsymbol{X}}$ & SS & $t$ \\
\hline I. Sınıfın Düzenlenmesi & 7.47 & 1.63 & 7.33 & 2.16 & .475 \\
\hline Mobilyaların düzenlenmesi & 10.83 & 3.32 & 9.91 & 3.02 & \\
\hline Trafik akışı & 5.64 & 1.69 & 5.16 & 1.69 & \\
\hline Farklı ilgi, yetenek ve kültüre göre sınıf malz. & 5.92 & 3.35 & 6.91 & 2.39 & \\
\hline II. Sınıfın Yönetimsel Org. & 3.00 & .61 & 3.11 & .96 & -.432 \\
\hline Günlük akış & 3.16 & .93 & 3.25 & .86 & \\
\hline Kurallar ve beklentiler & 2.08 & 1.44 & 2.66 & 2.14 & \\
\hline Organizasyonla ilgili sistematik & 3.64 & .74 & 3.41 & 1.08 & \\
\hline III. Sınıf Yönetimi Teknikleri & 9.40 & 2.51 & 9.77 & 1.93 & .733 \\
\hline Öğretmen ve çocuklar arasındaki etkileşim & 11.85 & 3.50 & 12.18 & 3.37 & \\
\hline Pekiştireç, geri bildirim ve ödül kullanımı & 8.42 & 1.74 & 8.54 & 1.29 & \\
\hline Birlikte problem çözmeleri & 8.71 & 3.14 & 10.54 & 1.50 & \\
\hline Beklentileri pekiştiren süreçler & 4.14 & 1.70 & 3.54 & 1.12 & \\
\hline Geçişler & 11.57 & 4.07 & 12.60 & 3.16 & \\
\hline Çocukların gözlemlenmesi ve rehberlik edilmesi & 11.71 & 4.10 & 11.45 & 3.44 & \\
\hline
\end{tabular}

\footnotetext{
${ }^{2}$ Çatışma Dönüştürme Becerileri Ölçeği kullanılarak yapılan ön ve son değerlendirmede sadece 14 çocuk eşleştirilebildiği için yapılamamıştır.
} 


\begin{tabular}{llllll}
\hline IV. Sınıftaki Sosyal Atmosfer & $\mathbf{1 1 . 2 0}$ & $\mathbf{3 . 0 8}$ & $\mathbf{1 1 . 7 5}$ & $\mathbf{4 . 0 2}$ & $\mathbf{- . 0 1 2}$ \\
Yetişkinler arasındaki etkileşimler & 9.15 & 4.74 & 8.20 & 4.10 & \\
Öğretmenlerin çocuklarla etkileşimleri & 10.35 & 2.34 & 10.16 & 1.99 & \\
Çocuklar arasındaki etkileşimler & 17.07 & 5.49 & 17.45 & 5.27 & \\
Çocuklar için öğretmen desteği & 8.14 & 2.85 & 10.66 & 6.42 & \\
Toplam & $\mathbf{7 . 7 8}$ & $\mathbf{1 . 7 3}$ & $\mathbf{7 . 8 9}$ & $\mathbf{2 . 0 1}$ & $\mathbf{. 2 6 7}$
\end{tabular}

Ön (42 gözlem) ve son (32 gözlem) test sonuçlarında öğrenci davranışları arasında gözlemlenen bazı değişiklikler kaydedilmiştir. Tablo 2, ölçekte var olan 10 olumlu ve 10 olumsuz davranışın ortalaması, standart sapması ve toplam puan hesaplamalarını göstermektedir. Veriler genel anlamda olumlu davranışlar üzerinde bir değişikliği işaret etmememektedir. Olumlu öğrenci davranışlarıyla ilgili, ön ve son test arasında farklar, Kargaşa çözümü ve kararsızıkların giderilmesi ve Karar verme davranışları arasında, daha küçük farklar ise Diğer çocukların ihtiyaç ve duygularına duyarlılık, Liderlik, Sözlü destek ve yüreklendirmede görülmüştür.

Olumsuz davranış ön ve son test verilerine bakıldığında ise daha farklı bir tablo göze çarpmaktadır. Olumsuz davranışların tümünde bir düşüş söz konusu olmuştur. Şöyle ki: Bencillik ve ödün vermekten kaçınma $(\bar{X} 1=.71, T 1=30 ; \bar{X} 2=.34, T 2=9)$, Utangaçlık, kendini geri çekme, endişeli olma durumu $(\bar{X} 1=.19, \mathrm{~T} 1=8 ; \bar{X} 2=.19, \mathrm{~T} 2=5)$, Kayıtsızlık, soğuk davranma $(\bar{X} 1=.26, \mathrm{~T} 1=11 ; \bar{X} 2=.15, \mathrm{~T} 2=4)$, Patronluk taslama ve zorbalık $(\bar{X} 1=.73, \mathrm{~T} 1=31 ; \bar{X} 2=.88, \mathrm{~T} 2=23)$, Kabalık, soğuk konuşma ( $\bar{X} 1=.50, T 1=21 ; \bar{X} 2=.26, T 2=7)$, Aşağılama, isim takma ( $\bar{X} 1=.28, T 1=12$; $\bar{X} 2=.11, \mathrm{~T} 2=3)$, Kavga etme, tartışma $(\bar{X} 1=.45, \mathrm{~T} 1=19 ; \bar{X} 2=.61, \mathrm{~T} 2=16)$, Anlaşmazlık yaratma, problemlerin çözümünü engelleme $(\bar{X} 1=.35, T 1=15 ; \bar{X} 2=.30, T 2=8)$, Sorumluluktan, işten ve karar vermeden kaçınma $(\bar{X} 1=.42, T 1=18 ; \bar{X} 2=.07, T 2=2)$, Dikkat dağınıklığı, umursamazlık $(\bar{X} 1=.85, \mathrm{~T} 1=36 ; \bar{X} 2=.19, \mathrm{~T} 2=21)$. Tüm olumsuz davranışların değerlerine bakıldığında yüksek oranda bir düşüş gözlemlenmektedir $(\bar{X} 1=4.78, T 1=201 ; \bar{X} 2=3.15, \mathrm{~T} 2=82)$.

Bu ölçekte analiz birimi çocukların bireysel olarak davranışları olmayıp grup davranışlarının gözlemlenip puanlanması olduğu için ön ve son test analizler karşılaştırmalı olarak yapılamamıştır. Bu nedenle iki veri grubu arasındaki gözlemlenen farkların istatistiksel olarak anlamlı olup olmadıkları test edilememiştir.

Tablo 2

Öğrenci Davranışları Gözlem Ölçeği Ortalama, Standart Sapma ve Toplam Değerler

\begin{tabular}{|c|c|c|c|c|c|c|c|c|c|}
\hline Davranış & Özellik & & $\bar{X}$ (SS) & $T$ & Davranış & Özellik & & $\bar{X}$ (SS) & $T$ \\
\hline \multirow[t]{6}{*}{$\begin{array}{l}\text { Olumlu } \\
\text { Davranış }\end{array}$} & \multirow[t]{2}{*}{ Yardımseverlik } & Ön & $\begin{array}{l}1.45 \\
(1.51)\end{array}$ & 61 & \multirow[t]{6}{*}{$\begin{array}{l}\text { Olumsuz } \\
\text { Davranış }\end{array}$} & \multirow{2}{*}{$\begin{array}{l}\text { Bencillik / ödün } \\
\text { vermekten } \\
\text { kaçınma }\end{array}$} & Ön & $\begin{array}{l}.71 \\
(1.27)\end{array}$ & 30 \\
\hline & & Son & $\begin{array}{l}.88 \\
(1.10)\end{array}$ & 23 & & & Son & $\begin{array}{l}.34 \\
(.84)\end{array}$ & 9 \\
\hline & \multirow{2}{*}{$\begin{array}{l}\text { İşbirliği ve } \\
\text { akranlarla } \\
\text { anlaşma }\end{array}$} & Ön & $\begin{array}{l}1.07 \\
(1.04)\end{array}$ & 45 & & \multirow{2}{*}{$\begin{array}{l}\text { Utangaçlık,kendini } \\
\text { geri çekme, } \\
\text { endişeli olma } \\
\text { durumu }\end{array}$} & Ön & $\begin{array}{l}.19 \\
(.45)\end{array}$ & 8 \\
\hline & & Son & $\begin{array}{l}.76 \\
(.65)\end{array}$ & 20 & & & Son & $\begin{array}{l}.19 \\
(.80)\end{array}$ & 5 \\
\hline & \multirow{2}{*}{$\begin{array}{l}\text { Diğer çocukların } \\
\text { ihtiyaç ve } \\
\text { duygularına } \\
\text { duyarlılık }\end{array}$} & Ön & $\begin{array}{l}.19 \\
(.55)\end{array}$ & 8 & & \multirow[t]{2}{*}{$\begin{array}{l}\text { Kayıtsızlık, soğuk } \\
\text { davranma }\end{array}$} & Ön & $\begin{array}{l}.26 \\
(.54)\end{array}$ & 11 \\
\hline & & Son & $\begin{array}{l}.38 \\
(.80)\end{array}$ & 10 & & & Son & $\begin{array}{l}.15 \\
(.36)\end{array}$ & 4 \\
\hline
\end{tabular}




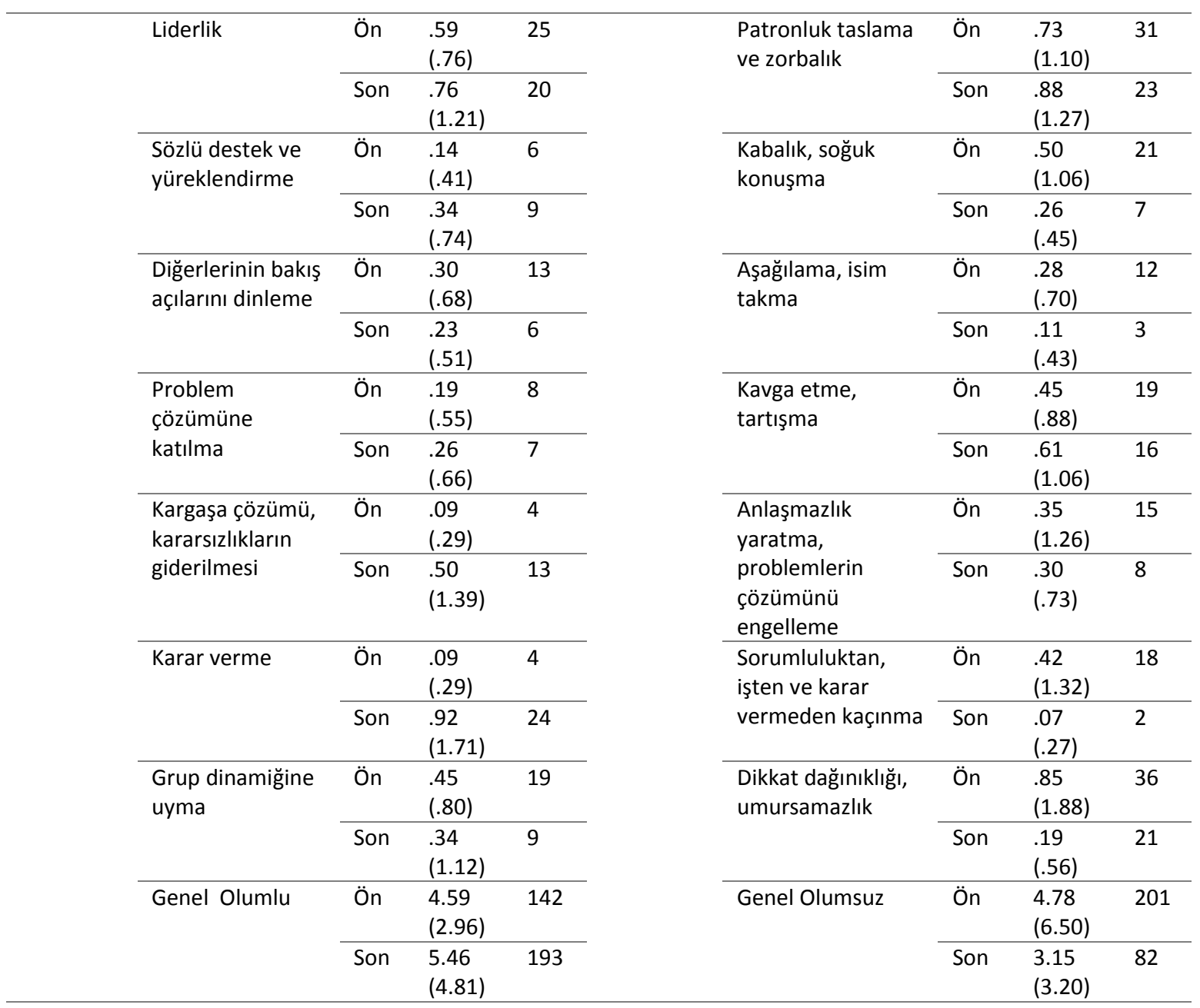

Okul Algısı Ölçeği ön testte 50 öğrenciye son testte 45 öğrenciyle uygulanmıştır. Ön ve son testte öğrencilerin Okul Algısı Ölçeği'ndeki sorulara verdikleri cevapların yüzdelik hesapları Tablo 3'te verilmiştir. Tabloda görüldüğü üzere öğrencilerin okullarına, sınıflarına, öğretmenlerine karşı olan algıları hem ön test hem de son test verilerine göre olumludur.

Ön ve son test verilerinde en çok olumlu cevap alınan maddeler sırasıyla: "Okulunu seviyor musun?" (\%98; \%100), "Okulda olmaktan hoşlanıyor musun?" (\%96; \%88.9), "Öğretmenin güvenilir biri mi?" (\%96; \%100) maddeleridir. Yine "Öğretmenin verdiği sözü tutar mı? (\%94; \%88.9) ve "Öğretmenin sana önem veriyor mu?" (\%86; \%84.4). "Başka bir okula gitmek ister misin?" sorusuna verilen yüksek orandaki hayır cevabı (\%88; \%88.9) ile birlikte düşünüldüğünde, öğrencilerin genel anlamda okullarıyla ve öğretmenleriyle ilgili olumlu duygu ve düşüncelere sahip oldukları görülmektedir.

Öğrencilerin akademik anlamda kendilerini algılayışları da yine olumludur. Başarııı olduğunu ve okulda istenenleri çok iyi yaptığını düşünenlerin oranı yüksektir (sırasıyla \%82, $\% 83.7$ ve \%84, \%80). Bu verilerin de yine öğrencilerin okulla ilgili olumlu düşüncelerin bir yansıması olduğunu düşündürtmektedir.

Tamamen olumsuz olarak algılanmaması gerekse de, öğrencilerin bazı sorulara verdikleri cevaplara detaylı bakmakta fayda vardır. Örneğin "Sınıfta sıkılıyor musun?" sorusuna verilen cevaplar dikkat çekicidir. Bu soruya hayır şeklinde cevap verenler azımsanmayacak çoğunluktayken (\%62; \%66.7), evet diyenler (\%16; \%13.3), bazen diyenler (\%22; \%20) yani ön 
testte toplamda \%38, son testte toplamda \%33.3'lük bir kısmını oluşturmaktadır. Toplamda sınıf genelinin üçte biri sınıfta sıkıldığını söylemektedir.

Sınıflarda yaşanan olumsuz bir durumu işaret eden diğer bir nokta da yine dikkate değer görünmektedir. Ön ve son test arasında olumlu yönde gelişen bir durum söz konusu olsa da "Sınıfta öğrenciler birbirlerine kaba davranır mı?" sorusuna verilen cevaplar sınıf içinde şiddetin sinyallerini vermektedir. Bu soruya evet şeklinde cevap verenler sınıfın hemen hemen yarısını oluşturmaktadır (\%48; \%40). Öğrencilerin birbirlerine "bazen" kaba davrandığını dile getirenler (\%9; \%26.7), bu soruya evet şeklinde cevap verenler ise (\%34; \%33.3) oranlarındadır. Evet ve bazen cevapları bir arada düşünüldüğünde, sınıfın yaklaşık yarısı sınıfta şiddetin var olduğunu dile getirmektedir.

Öğrenciler tarafından verilen cevaplar, yaşanan şiddetin diğer göstergelerinin de sınıflarda mevcut olduğunu göstermektedir. "Öğretmenin sana ceza verir mi?" sorusuna verilen cevaplarda sınıfın yine yarısı cezanın söz konusu olmadı̆ı̆ını ifade ederken (\%44; \%51.1), bu soruya cezanın bazen söz konusu olduğunu söyleyenler (\%24; \%31.1) cezanın var olduğunu söyleyenler (\%32; \%17.8) oranlarındadır. Bazen ve evet cevapları bir arada düşünüldüğünde, öğrencilerin yarısının öğretmenleri tarafından cezalandırıldıklarını ifade ettikleri görülmektedir. Benzer şekilde cevaplandırılan fakat oranları daha yüksek olan, "Ne zaman hata yapsanız öğretmeniniz sinirleniyor mu?" sorusuna hayır cevabı verenler (\%34; \%22.2), bazen cevabı verenler (\%12; \%28.9) ve evet cevabı verenler ise (\%54; \%48.9). Görüldüğü üzere öğretmenlerin hatalara karşı sinirlenme davranışı gösterme oranı bazen ve evet cevapları bir arada değerlendirildiğinde ön testte $\% 66$, son testte ise $\% 62$ oranındadır.

Sınıfta mevcut olması beklenen öğrenci otonomisi, özellikle birlikte karar verme ile ilgili sorularda ön ve son test verileri arasında olumlu yönde farklılıklar göze çarpsa da, öğrencilerin karar aşamalarında fazlaca söz hakkına sahip olmadıkları açıktır. "Sınıfta yapacaklarınıza öğretmenin mi karar verir?" sorusuna yüksek oranda ifade edilebilecek bir çoğunluk evet demiştir (\%94; \%80). "Öğretmeniniz bazı kararları alırken sizin fikrinizi sorar mı?" sorusunda ise bir dağılım söz konusudur. Sınıfın hemen hemen yarısı öğretmenlerinin karar alırken onlara danıştığını söylese de (\%48; \%55.6), diğer yarısı, bize danışmaz (\%20; \%24.4) veya bazen danışır (\%32; \%20) cevaplarını vermişlerdir.

Ön ve son test verilerinin yüzdeliklerine bakıldığında bazı farklar göze çarpmaktadır. Örneğin "Okulun eğlenceli bir yer midir?" sorusuna ön testte \%88 son testte \%95.5 oranında olumlu cevap verilmiştir. Benzer bir soru olan "Sınıfta yaptıklarından keyif alıyor musun?" sorusuna yine aynı şekilde öğrencilerin verdiği olumlu cevap \%80 iken, bu oran \%97.8'e yükselmiştir.

Ön ve son test verileri karşılaştırıldığında yüzdelik hesaplamalarda başka bir farklıık "Öğretmenin hepinize eşit davranır mı?" sorusuna verilen cevaplarda görülmektedir. Öğrencilerin olumlu cevaplarında bir artış olduğu (\%64; \%84.4) gözlemlenmektedir. Yine "Sınıf kurallarına öğretmen ve öğrenci hep birlikte mi karar verirsiniz?" sorusuna olumlu cevaplarda artış (\%38; \%60) olumsuz cevaplarda ise bir düşüş (\%48; \%35.6) göze çarpmaktadır.

Ön ve son test verilerinde bazı göstergeler ise yorumlamada zorluk yaşanmasına yol açmaktadır. Öğrenci otonomisi, özellikle kendi başına karar verme konusunda olumlu yönde değişim beklenmekteyken kararlarını kendi başına verme konusunda olumlu görüşlerde düşüş (\%48; \%22.2), olumsuz görüşlerde artış (\%40; \%60); başkalarının kendisi yerine karar verme isteğinde olumlu yönde yine bir düşüş (\%86; \%62.2), olumsuz yönde bir artış (\%6; \%33.3) gözlemlenmektedir. 
Aynı şekilde kendilik algısı ile ilgili beklentilerin ters yönünde bir hareket söz konusudur. "Kendini olduğun gibi seviyor musun?" sorusuna verilen cevaplardaki değişim (\%98; \%86.7), "Keşke olduğumdan farklı biri olsaydım diyor musun?" sorusuna verilen cevaplardaki değişim (\%78; \%84.4) oranlarındadır. Akademik konularda kendilik algısıyla ilgili bir soruda yine beklentilerin dışında bir durum söz konusu olmuştur. "Okulda başarısız olduğun duygusuna kapılıyor musun?" sorusuna evet diyenlerin oranı \%14'ten \%28.9'a çıkarken hayır diyenler \%68'den \%48.9'a düşmüştür.

Tablo 3

Öğrencilerin Okul Algısı Ölçeği Ön ve Son Test Cevap Yüzdeleri

\begin{tabular}{|c|c|c|c|c|c|c|c|}
\hline & & Evet & & Hayır & & Baze & \\
\hline Kavram & Madde & $\begin{array}{l}\text { Ön } \\
(\%)\end{array}$ & $\begin{array}{l}\text { Son } \\
(\%)\end{array}$ & $\begin{array}{l}\text { Ön } \\
\text { (\%) }\end{array}$ & $\begin{array}{l}\text { Son } \\
(\%)\end{array}$ & $\begin{array}{l}\text { Ön } \\
(\%)\end{array}$ & $\begin{array}{l}\text { Son } \\
(\%)\end{array}$ \\
\hline \multirow[t]{4}{*}{ Okul Sevgisi } & Okulunu seviyor musun? & 98 & 100 & 0 & 0 & 0 & 0 \\
\hline & $\begin{array}{l}\text { Başka bir okula gitmek ister } \\
\text { misin? (ters) }\end{array}$ & 4 & 6.7 & 88 & 88.9 & 8 & 4.4 \\
\hline & Okulun eğlenceli bir yer midir? & 88 & 95.5 & 2 & 0 & 10 & 4.5 \\
\hline & $\begin{array}{l}\text { Okulda olmaktan hoşlanıyor } \\
\text { musun? }\end{array}$ & 96 & 88.9 & 0 & 8.9 & 4 & 2.2 \\
\hline \multirow[t]{4}{*}{$\begin{array}{l}\text { Sınıf } \\
\text { Dayanışması }\end{array}$} & $\begin{array}{l}\text { Sınıfta yaptıklarından keyif alıyor } \\
\text { musun? }\end{array}$ & 80 & 97.8 & 10 & 0 & 10 & 2.2 \\
\hline & Sınıfta sıkılıyor musun? (ters) & 16 & 13.3 & 62 & 66.7 & 22 & 20 \\
\hline & $\begin{array}{l}\text { Sınıfta birbirinize yardım eder } \\
\text { misiniz? }\end{array}$ & 96 & 91.1 & 2 & 2.2 & 2 & 6.7 \\
\hline & $\begin{array}{l}\text { Sınıfınızda öğrenciler birbirine } \\
\text { kaba davranır mı? (ters) }\end{array}$ & 48 & 40 & 34 & 33.3 & 18 & 26.7 \\
\hline \multirow{6}{*}{$\begin{array}{l}\text { Öğretmene } \\
\text { Güven } \\
\text { Duyma }\end{array}$} & $\begin{array}{l}\text { Öğretmenin sana önem veriyor } \\
\text { mu? }\end{array}$ & 86 & 84.4 & 6 & 4.4 & 8 & 11.1 \\
\hline & Öğretmenin güvenilir biri mi? & 96 & 100 & 0 & 0 & 4 & 0 \\
\hline & $\begin{array}{l}\text { Öğretmenin verdiği sözü tutar } \\
\text { mı? }\end{array}$ & 94 & 88.9 & 2 & 2.2 & 4 & 8.9 \\
\hline & $\begin{array}{l}\text { Öğretmenin hepinize eşit } \\
\text { davranır mı? }\end{array}$ & 64 & 84.4 & 12 & 8.9 & 24 & 6.7 \\
\hline & $\begin{array}{l}\text { Öğretmenin sana ceza verir mi? } \\
\text { (ters) }\end{array}$ & 32 & 17.8 & 44 & 51.1 & 24 & 31.1 \\
\hline & $\begin{array}{l}\text { Ne zaman bir hata yapsanız } \\
\text { öğretmeniniz sinirleniyor mu? } \\
\text { (ters) }\end{array}$ & 54 & 48.9 & 34 & 22.2 & 12 & 28.9 \\
\hline \multirow[t]{4}{*}{$\begin{array}{l}\text { Öğrenci } \\
\text { Otonomisi }\end{array}$} & $\begin{array}{l}\text { Sınıfta yapacaklarınıza } \\
\text { öğretmenin mi karar verir? (ters) }\end{array}$ & 94 & 80 & 4 & 11.1 & 2 & 8.9 \\
\hline & $\begin{array}{l}\text { Sınıf kurallarına öğretmen ve } \\
\text { öğrenci hep birlikte mi karar } \\
\text { verirsiniz? }\end{array}$ & 38 & 60 & 48 & 35.6 & 14 & 4.4 \\
\hline & $\begin{array}{l}\text { Öğretmeniniz bazı kararlar } \\
\text { alırken sizin fikrinizi sorar mı? }\end{array}$ & 48 & 55.6 & 20 & 24.4 & 32 & 20 \\
\hline & $\begin{array}{l}\text { Kararlarını kendin verebilir } \\
\text { misin? }\end{array}$ & 48 & 22.2 & 40 & 60 & 12 & 17.8 \\
\hline
\end{tabular}


Oyun Temelli Deneyimlerin Sınıf Ortamı, Öğrencilerin Davranışları, Okul Algıları ve Çatışma Dönüştürme Becerilerine Etkisi

Mine GÖL-GÜVEN

\begin{tabular}{|c|c|c|c|c|c|c|c|}
\hline & $\begin{array}{l}\text { Başkaları senin yerine karar } \\
\text { versin ister misin? (ters) }\end{array}$ & 6 & 33.3 & 86 & 62.2 & 8 & 4.4 \\
\hline \multirow[t]{2}{*}{ Özgüven } & $\begin{array}{l}\text { Kendini olduğun gibi seviyor } \\
\text { musun? }\end{array}$ & 98 & 86.7 & 2 & 8.9 & 0 & 4.4 \\
\hline & $\begin{array}{l}\text { Keşke olduğumdan farklı biri } \\
\text { olsaydım diyor musun? (ters) }\end{array}$ & 10 & 4.4 & 78 & 84.4 & 12 & 11.1 \\
\hline \multirow{4}{*}{$\begin{array}{l}\text { Akademik } \\
\text { Özgüven }\end{array}$} & Başarılı bir öğrenci misin? & 82 & 83.7 & 6 & 7 & 12 & 9.3 \\
\hline & $\begin{array}{l}\text { Öğretmenin anlattığını } \\
\text { anlamadığın zamanlar oluyor } \\
\text { mu? (ters) }\end{array}$ & 30 & 28.9 & 44 & 37.8 & 26 & 33.3 \\
\hline & $\begin{array}{l}\text { Okulda senden istenenleri çok } \\
\text { iyi yapıyor musun? }\end{array}$ & 84 & 80 & 6 & 4.4 & 10 & 15.6 \\
\hline & $\begin{array}{l}\text { Okulda başarısız olduğun } \\
\text { duygusuna kapılıyor musun? } \\
\text { (ters) }\end{array}$ & 14 & 28.9 & 68 & 48.9 & 18 & 22.2 \\
\hline
\end{tabular}

Öğrencilerin okul algısındaki farklarda ise (Tablo 4), sınıfta yapılanlardan keyif alma $(t(49)=2.796, p<.001)$; öğretmenlerin öğrencilere eşit davranması $(t(49)=2.757, p<.05)$; sınıf kurallarına öğrenci ve öğretmenler birlikte karar vermesi başlıklarında, ön ve son test ortalamaları arasında istatistiksel anlamlılık bulunmuştur $(\mathrm{t}(49)=2.289, \mathrm{p}<.05)$. Beklentilerin aksine, kendilik algısı (özgüven) ve akademik özgüven (akademik anlamda başarılı olma) ön ve son test ortalamaları arasında düşüş kaydedilmiştir.

Tablo 4

Öğrencilerin Okul Algısı Ölçeği Maddelere Bağlı Ortalama, Standart Sapma, $t$ Test ve p Değerleri

\begin{tabular}{|c|c|c|c|}
\hline Madde & & $\bar{X} /$ SS & $t$ test (p) \\
\hline \multirow[t]{4}{*}{ Sınıfta yaptıklarından keyif alıyor musun? } & Ön & 2.63 & \multirow{4}{*}{$\begin{array}{l}2.796 \\
(.009)^{*}\end{array}$} \\
\hline & & $(.71)$ & \\
\hline & Son & 3 & \\
\hline & & (0) & \\
\hline \multirow[t]{3}{*}{ Öğretmenin hepinize eşit davranır mı? } & Ön & 2.56 & \multirow{3}{*}{$\begin{array}{l}2.757 \\
(.01)^{*}\end{array}$} \\
\hline & & (.67) & \\
\hline & Son & 2.86 & \\
\hline \multirow{4}{*}{$\begin{array}{l}\text { Sınıf kurallarına öğretmen ve öğrenci hep } \\
\text { birlikte mi karar verirsiniz? }\end{array}$} & Ön & 1.80 & \multirow{4}{*}{$\begin{array}{l}2.289 \\
(.03)^{*}\end{array}$} \\
\hline & & $(.92)$ & \\
\hline & Son & 2.30 & \\
\hline & & $(.95)$ & \\
\hline \multirow[t]{4}{*}{ Kararlarını kendin verebilir misin? } & Ön & 2.13 & \multirow{4}{*}{$\begin{array}{l}-2.902 \\
(.007)^{*}\end{array}$} \\
\hline & & $(1.00)$ & \\
\hline & Son & 1.53 & \\
\hline & & $(.81)$ & \\
\hline \multirow{4}{*}{$\begin{array}{l}\text { Başkaları senin yerine karar versin } \\
\text { ister misin?(ters) }\end{array}$} & Ön & 2.83 & \multirow{4}{*}{$\begin{array}{l}-2.984 \\
(.006)^{*}\end{array}$} \\
\hline & & $(.46)$ & \\
\hline & Son & 2.26 & \\
\hline & & $(.94)$ & \\
\hline \multirow[t]{4}{*}{ Kendini olduğun gibi seviyor musun? } & Ön & 2.93 & \multirow{4}{*}{$\begin{array}{l}-1.795 \\
(.08)^{*}\end{array}$} \\
\hline & & $(.36)$ & \\
\hline & Son & 2.73 & \\
\hline & & (.69) & \\
\hline \multirow{4}{*}{$\begin{array}{l}\text { Okulda başarısız olduğun duygusuna } \\
\text { kapılıyor musun?" (ters) }\end{array}$} & Ön & 2.50 & \multirow{4}{*}{$\begin{array}{l}-2.083 \\
(.04)^{*}\end{array}$} \\
\hline & & $(.77)$ & \\
\hline & Son & 2.13 & \\
\hline & & (.89) & \\
\hline
\end{tabular}


Öğrencilere çatışma içeren 6 farklı durum verilmiş ve sunulan çözüm önerilerinden birini tercih etmeleri istenmiştir. Cevap alındıktan sonra önerisinin işe yaramadığı durumda yeniden çözüm önerileri sunulmuş ve birini seçmesi istenmiştir. Durumlara verilen cevapların ön ve son test yüzdelerine bakıldığında bağlama uygun olarak ölçeğe sonradan eklenen durum 5 ve durum 6 arasındaki farklar göze çarpmaktadır. Bu durumlar özellikle oyun esnasında karşılaşılabilecek çatışmalar olmasına dikkat edilmiştir (Grafik 1).

Durum 5 "Bütün sınıf hep beraber topla bir oyun oynuyorsunuz. Bu oyunu oynamayı çok seviyorsun, çok eğlenceli bir oyun. Yalnız oyunun kurallarından biri, top birine değdiğinde, topun değdiği kişi yanıyor ve oyundan çıkıyor. Bir anlığına dikkatin dağılıyor, başka tarafa bakarken top sana değiyor. Arkadaşların sana "top değdi sen yandın" diyor. Bu durumda ne yaparsın?" sorusuna uzlaşmacı tutumu benimseyen cevap verme yüzdeleri arasında \%13.6'lık bir artış olmuştur (\%52, \%65.6). Aynı duruma verilen saldırgan cevaplarda ise beklentilere uygun olarak \%21'lik bir düşüş görülmektedir $(\% 25, \% 4)$.

Durum 6 "Arkadaşlarınla birlikte bir oyun oynayacaksınız. Sen önerini yapamadan, arkadaşların oynanacak oyuna karar veriyorlar. Bu durumda ne yaparsın?" sorusuna verilen cevapların ön ve son değerlendirme yüzdelerine bakıldığında, uzlaşmacı tutumun \%15.75 oranında arttığı gözlemlenmektedir (\%60.75, \%76.5). Yine saldırgan tutumun \%15.15 oranında düşüş göstermesi dikkat çekicidir (\%24.3, \%8.65).

Öğrencilerin çatışma dönüştürme becerilerinde olumlu yönde bir ilerleme kaydedilmiştir. Ön ve son test yüzdelerine bakıldığında, öğrencilerin uzlaşmacı tutum puanları artmış, saldırgan, tutum puanları ise azalmıştır. En fazla artış, kurallara uyma ve öneri getirme durumlarında uzlaşmacı tutum puanlarında, en fazla düşüş ise saldırgan tutum puanlarında gözlemlenmiştir.

Grafik 1

Çatışma Dönüştürme Becerileri Ön ve Son Test Yüzdeleri

\section{Çatışma Dönüştürme Becerileri}

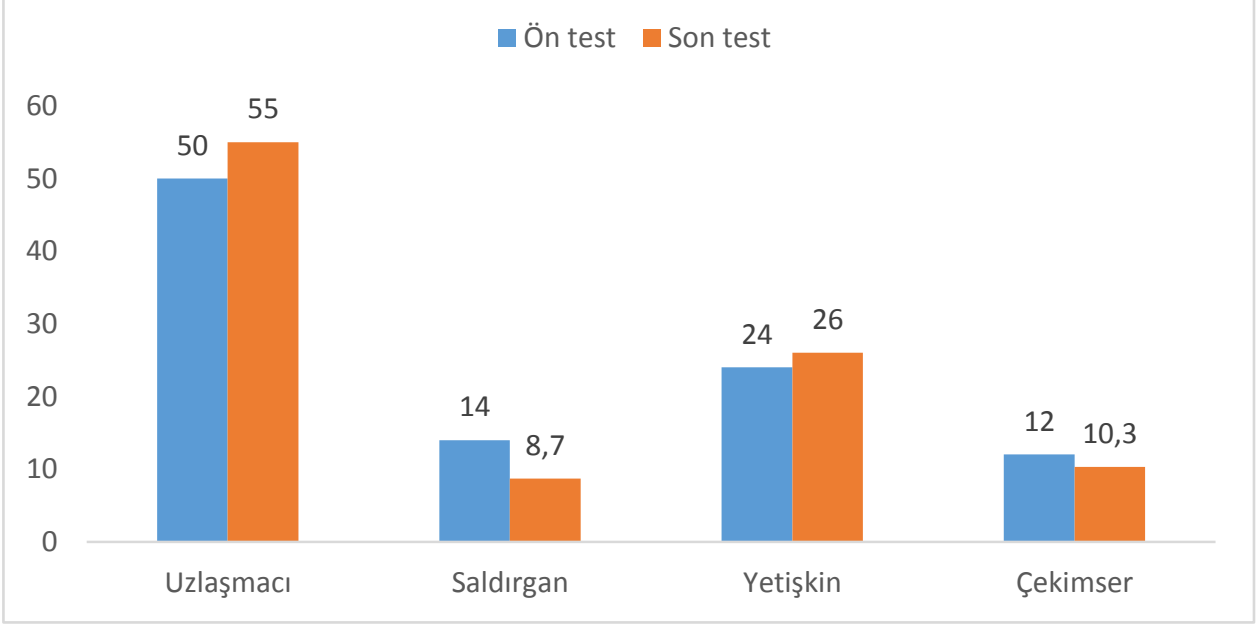

\section{SONUÇ, TARTIŞMA VE ÖNERILER}

Araştırmada erken çocukluk gelişim özelliklerine uygun bir ortamın iKDOP programı vasıtasıyla sağlanmasının sınıf ortamına, öğrenci davranışlarına, okul algısına ve çatışma çözme 
becerilerine etkililiği incelenmiştir. Bulgular, sınıfın fiziksel ve sosyal ortamında ön ve son değerlendirme verileri karşılaştırıldığında olumlu yönde ilerlediği kaydedilmişse de, bu farklar istatistiksel anlamlılık derecesine ulaşmamıştır.

Sınıfların fiziksel durumu beklentileri karşılamamaktadır. Sınıfların temizlik ve bakım ile ilgili sorunları göze çarpan ilk konulardan biridir. Gözlem yapılan çoğu sınıfta sınıfların küçük ve kalabalık olduğu gözlemlenmiştir. Sınıflarda öğretmen ilgisi görmeden, etrafa boş gözle bakan ve sıralar arasında dolaşarak günü tamamlayan çocuklar olduğu görülmüştür. Ayrıca sınıflar arasındaki öğrenci mevcudundaki farklar bu konuda bir standardın oluşturulmadığını göstermektedir. Bir okuldaki sınıf mevcudu 13 iken diğer bir okulun sınıf mevcudu 39 olabilmektedir. Bu büyüklükteki bir farkın doğal olarak sınıf ve öğretmen uygulamalarına yansıması, öğrenci ve öğretmenlerin etkinlik düzeyini olumsuz yönde etkilemesi kaçınılmazdır.

Bazı sınıfların ikili öğretim sisteminde işleyişi ise başka bir problem olarak göze çarpmaktadır. Sınıf mobilyaları, özellikle öğrenci sıraları ilkokul 1. sınıf öğrencilerinin boyutlarına göre değil, ortaokul öğrencilerinin boyutlarına göre sınıflara yerleştirilmiştir. Gözlemlerde bir çok 1 . sınıf öğrencisinin ayakta yazı yazmaya çalıştığı veya ayaklarını altına toplayarak sırada oturduğu görülmüştür. Bu durum sınıfların organizasyonel yapısını (sınıf/davranış yönetimi) ve bu yönde kullanılan görselleri de etkilemektedir. Sınıfta ya hiç bir görsel yoktur ya da kullanılan bir çok görsel 1.sınıf çocuğuna hitap etmemektedir (örneğin, İstanbul'un fethini anlatan tarihi resimler, İstanbul ilinin jeofizik haritası veya Eyüp semtindeki tarihi yapılar ve mezarlıklar gibi), yaşlarına uygun olanlar da çocukların göz seviyelerinin çok üzerindedir veya kullanılmıyormuş hissi uyandırmaktadır (kenarları yırtık, eskimiş). Bunun da ötesinde sınıfların gelişimsel olarak uygun hale dönüştürülmesi için gerek çocuklarla birlikte yürütülen çalışmaların (örneğin arkadaşlık tarlası) gerekse program uygulayıcıların hazırladığı sınıf yönetimini kolaylaştırıcı görsellerin (sınıf kuralları gibi) ertesi gün duvarlardan söküldüğü gözlemlenmiştir. Görüleceği üzere, ikili öğretim mevcut durumda olumsuz bir durum ortaya koymakla birlikte, olumsuzu olumlaya dönüştürme çabalarını da kaldıramamaktadır.

Sınıfların mümkün olduğunca çok çocuk alabilmesi ve ikili öğretimle sınıflardan maksimum bir şekilde faydalanılması istekleri, sınıf yönetiminde olduğu gibi öğretim yöntem ve süreçleri açısından da olumsuzlukları beraberinde getirmektedir. Örneğin yapılan hiçbir gözlemde çocukların bireysel veya küçük grupla çalışmalar yaptığı görülmemiştir. Çocuklar büyük grup (sınıf) halinde tutulmakta, tek bir yönerge ile yapılan tek bir çalışma ile başarıları değerlendirilmektedir. Büyük grupla yapılan çalışmalarda ise sınıfın geleneksel konumu olarak adlandırılan, tahtaya ve dolayısıyla tahtanın önünde duran öğretmene bakan sıralarda oturan çocuklar gözlemlenmiştir. Akranla etkileşim sonucu öğrenme, işbirliğine dönük grup çalışması yok denecek kadar azdır. Bu durumun yarattığı olumsuzluklar Martlew v.d. (2011) tarafından da dile getirilmiştir. Bu çalışmaya göre öğrencilerin büyük grup olarak ve öğretmen yönetiminde ders işlemesi, program oyun temelli olsa da akran işbirliği ve etkileşimini olumsuz yönde etkilemektedir.

Öğretmenin yönetimsel ve yöntemsel davranışlarına odaklanacak olunursa, öğrenci performansının değerlendirilmesinde sıkıntıların mevcudiyeti göze çarpmaktadır. Öğrencilerin ürettikleri hiçbir ürünün sergilenmediği gözlemlenmiştir. Yapılanlar deftere yazılan yazılar veya matematik problemlerinin çözümünden ibaret olmakta, bunlar da ya öğretmenin dikte ettiği metinler ya da tahtaya yazdıkları öğrenciler tarafından kopya edilen cümleler veya yazılar olmaktadır. Performansa veya yaratıcılı̆̆a dayalı herhangi bir etkinlik gözlemlenmemiştir. Dolayısıyla öğrencilerin ürettiği şeyler defterde hapsolan sayılar ve yazılardan başka bir şey olmamakta, bunların da sergilenecek bir özelliği bulunmamaktadır. 
Olumlu öğrenci davranışlarıyla ilgili, ön ve son test arasında farklar, Kargaşa çözümü ve kararsızıkların giderilmesi ve Karar verme davranışları arasında, daha küçük farklar ise Diğer çocukların ihtiyaç ve duygularına duyarlılık, Liderlik, Sözlü destek ve yüreklendirmede görülmüştür. Olumsuz davranış ön ve son test verilerine bakıldığında ise daha farklı bir tablo göze çarpmaktadır. Olumsuz davranışların tümünde bir düşüş söz konusu olmuştur. Bencillik ve ödün vermekten kaçınma; Utangaçlık, kendini geri çekme, endişeli olma durumu; Kayıtsızıı, soğuk davranma; Patronluk taslama ve zorbalık; Kabalık, soğuk konuşma; Aşağılama, isim takma; Kavga etme, tartışma; Anlaşmazlık yaratma, problemlerin çözümünü engelleme; Sorumluluktan, işten ve karar vermeden kaçınma; Dikkat dağınıklığı, umursamazlık. Tüm olumsuz davranışların değerlerine bakıldığında yüksek oranda bir düşüş gözlemlenmektedir. Bu bulgular sosyo-duygusal becerilerin oyun yoluyla desteklenmesi ile ilgili alanyazında varolan diğer çalışmaları desteklemektedir (Broadhead, 2015; Pramling Samuelsson ve Johansson, 2006; Whitebread, 2012).

Öğrenci otonomisine ve eşitliğe fırsat tanıyan bir çevre gözlemlenememiştir. Öğretmenlerin karar aldığı ve uyguladığı, öğrencilerin bu kararlarda herhangi bir rol almadığı gözlemlenmiştir. Bu durumu öğrencilerle yapılan görüşmeler de işaret etmiştir. Yine öğrencilerle yapılan görüşmelerde öğrencilerin karar almada etkin rol üstlenmek istedikleri de ortaya çıkmıştır. Ön ve son test verilerinde programla hedeflenen sınıfta karar alma ve eşit davranılma durumunun olumlu yönde değişmesi önemli bir nokta olmuştur. Öğrencilerin eşit ve etkin rol üstlenmelerinin demokratik bir ortam yaratmada öneminin büyük olduğu bilinmektedir. Bu yönde yapılacak çalışmalar çok değerlidir.

Çocuklar yapılan görüşmelerde her ne kadar öğretmenin kendilerine eşit davrandığını söyleseler de sınıf gözlemleri bunu yansıtmamaktadır. Okuma-yazmayı henüz öğrenememiş çocukların ayağa kaldırılıp hem sınıf arkadaşları hem de ziyaretçilerin önünde ifşa edilmesi, bir öğrenciyle ilgili onun duyacağı şekilde ağabeyinin de böyle başarısız olduğunun ziyaretçiye söylenmesi, bir çocuğun kapıcı çocuğu olduğunun, bir çocuğun boşanmış aileden geldiğinin, ve tabi ki "küçüklerin" ayağa kaldırılıp "bunlar 60 aylık" gibi söylemlerin sıkça duyulması şaşırtıcıdır.

Öğrencilerin okul algısındaki farklarda ise, sınıfta yapılanlardan keyif alma; öğretmenlerin öğrencilere eşit davranması; sınıf kurallarına öğrenci ve öğretmenler birlikte karar vermesi başlıklarında, ön ve son test ortalamaları arasında istatistiksel anlamlılık bulunmuştur. Beklentilerin aksine, kendilik algısı (özgüven) ve akademik özgüven (akademik anlamda başarılı olma) ön ve son test ortalamaları arasında düşüş kaydedilmiştir. Katz'ın (1988) ne kadar erken o kadar iyi yaklaşımıyla çocukların başaramama duygusunu yaşadıkları ile ilgili görüşü bu bulgunun yorumlanmasında önemlidir.

Özgüven ve akademik özgüvendeki düşüş öğrencilerin çok az olumlu dönüt ve pekiştireç almaları ile açıklanabilir. Genel olarak öğretmenle öğrenciler arasında öğrencilerin neyi yanlış yaptıkları, neyi yapamadıkları, neyi tekrar yapmaları gerektiği ile ilgili konuşmalar geçmiştir. Oysaki bu yaş çocuklarının kendilik algıları yaptıklarıyla büyüklerinden onay aldıkça gelişir ve kendileriyle gurur duymaya başlarlar. Akademik yılın sonuna doğru yapılan bu son değerlendirme görüşmelerinde çocukların giderek artan bir şiddette başarılı olma (okumayazmayı öğrenme) stresi yaşamaları ve öğretmenlerin olumsuza odaklanmalarının da bu sonucun çıkmasında rolünün büyük olduğu düşünülmektedir.

Sınıf iklimini olumsuz yönde etkileyecek en vahim durum öğretmenin şiddet dili kullanmasıdır. Bu tür bir dil, tehdit unsuru barındırır ve bu durum öğrencilerin çelişkili davranmalarına yol açar. Her an azarlanacağı veya cezalandırımakla tehdit edileceği bir durumla karşılaşmamak için (veya karşılaştığında umursamamak için) aşırı uçlarda davranışlar 
(saldırgan veya sinmiş) ya yetişkinin varlığında ya da yokluğunu fırsat bilerek sergilenir. Çocukları küçük düşürücü, aşağılayıcı ve dalga geçen bir dil sınıflarda gözlemlenmiştir. Bunun yanı sıra bazı sınıflarda fiziksel şiddetin (kulak çekme, başa veya sırta hızlıca vurma) bire bir gözlemlenmesi veya çocuklar tarafında ifade edilmesi son derece üzücüdür.

Müfredat ve öğretim yöntemleri ile ilgili ise şu noktalar dikkat çekicidir. Gözlemlerde ve öğretmenlerle görüşmelerde tek ve öncelikli hedefin okuma-yazma öğretimi olduğu ortaya çıkmıştır. Bu yaş çocuklarının gelişimsel ihtiyaçlarının çeşitliliği göz önünde bulundurulduğunda bu hedefin son derece kısıtlayıcı olduğu görülmektedir. Çocukların kendilerini ifade edişlerinin çeşitliliği de (oyun, mış gibi yapma, resim, sosyal ilişkiler ve arkadaşlık gibi) düşünüldüğünde okuma-yazma yoluyla ifadenin çocukları dar bir alana sıkıştırmaktan başka bir şey olmadığı da açıkça görülebilir. Tek başarı göstergesi olarak görülen okuma-yazma öğrenimi yine çocuklar üzerinde baskı unsurudur. Çocuk ihtiyaçlarına hassas yaklaşımlar sadece 1.sınıf çocukları için değil tüm ilkokul süresince benimsenmelidir. Oyun kendini ifade edişte en önemli araçlardan biridir. Yaratıcılık, kendini ifade etme, sosyal ilişkileri yönetme, problem çözme gibi bir çok becerinin kazanılması oyunla olur. Fakat oyunun 10 dakikalık teneffüslere sıkıştırılmış olduğunu görmek bu yaş çocuğunun gelişimsel özelliklerinin bilinmediği ve bu özelliklere ve ihtiyaçlara uygun müfredat, öğretim yöntemleri ve bir okul günü planlayıp uygulanmadığını görmek demektir.

Öğrencilerin çatışma dönüştürme becerilerinde olumlu yönde bir ilerleme kaydedilmiştir. Öğrencilerin uzlaşmacı tutum ve yetişkin odaklı çözüm bulma puanları artmış, saldırgan ve çekimser tutum puanları ise azalmıştır. En fazla artış, kurallara uyma ve öneri getirme durumlarında uzlaşmacı tutum puanlarında, en fazla düşüş ise saldırgan tutum puanlarında gözlemlenmiştir.

Olumlu davranış becerilerini kazanmada sınıf içinde kullanılan görseller kadar öğretmenin bire bir rol model olması ve bu konuda liderlik görevi üstlenmesi önemlidir. Çocukların davranışları üzerine düşünmeleri ve sorunlarını çözmede, farklı çözüm yolları bulma ve denemede fırsat tanınması gerekir. Fakat yapılan gözlemler bunun tersini göstermektedir. Çocukların çatışma yaşaması ve bu çatışmaları öğretmenin varlığında, onun yönlendirmesi ve desteğiyle çözmeye çalışmaları istendik bir durumdur. Ancak bu deneyimler yaşandıkça ve olumlu bir deneyim olarak sonuçlandıkça çocuklar problem çözme becerileri kazanabilirler. Fakat öğretmenler ya hiç çatışma yaşanmaması için sert bir dil kullanmaktadırlar ya da çatışmalarda aşırı müdahaleci olup öğrenciler adına çözümler üretmektedirler. Burada yetişkinin varlığı ve çatışma yönetici rol üstlenmesi önemlidir. Ne yazık ki çatışmaların en çok görüldüğü teneffüslerde ve oyun alanlarında öğretmenler çocuklarla birlikte olmamaktadırlar. Özellikle küçük yaş çocuklarının bu ihtiyacı görülmeli ve bir yetişkin liderliğinde çatışma çözümü stratejilerini öğrenmeleri sağlanmalıdır.

Son olarak bu araştırmanın 4+4+4 eğitim sistemine geçiş yılı olan 2012-2013 eğitimöğretim yılında yapılması nedeniyle öğretmenlerin okula başlama yaşının 1 yıl öne alınması ile ilgili görüşlerine yer vermek gerekir. Öğretmenler özellikle küçük yaş grubunun gelişimsel özelliklerini bilmediklerinden hatta işlerinin çocuk bakıcılığı olmadığından bahsetmişlerdir. Çocukların öz bakım becerilerinden yoksun olduklarına sıkça değinmişlerdir. Araştırmaya katılan sınıfların bazıları erken yaş için özel açılmış, bazıları ise karma sınıflardan oluşmuştur. Hem ayrılan sınıflar hem de karma olan sınıfların öğretmenleri erken başlama uygulaması ile ilgili olumsuz görüş fade etmiştir. Karma olan sınıfların öğretmenleri küçük yaş grubunun ihtiyaçlarına hitap edemediklerini, onlara yetişemediklerini, onlarla ilgilenmeye çalışırken "asıl" birinci sınıf çocuklarıyla ilgilenemediklerini söylerken, ayrı olan sınıfların öğretmenleri ise (sadece 5-5,5 yaş çocuklarının olduğu sınıflar) çocukların birinci sınıfa hazır olmadıklarını ve bu durumun onları çok yorduğunu ifade ederek birleştirilmiş sınıfların daha iyi olabileceği önerisini 
getirmişlerdir. Birleştirilmiş veya ayrı sınıflar, öğretmenlerin küçük yaş grubuyla ilgili bilgilerinin olmaması ve bu konuda detaylı bir hizmet öncesi veya hizmet içi eğitim almamış olmaları, ne öğrencilere bir fayda ne de öğretmenlere bir kolaylık sağlamıştır.

Yapılan bu çalışmanın sonucu şunu göstermektedir: Uygulanan programın olumlu yönde değişiklikler kaydettiği görülse de, 1.sınıfların, fiziksel (sınıf mevcudu, sınıf mobilya ve materyalleri), yönetimsel (sınıf ve davranış yönetimi) ve yöntemsel (müfredat ve öğretim yöntemleri) durumlarının bu yaş grubunun gelişimsel özellikleri ve intiyaçları gözden geçirilerek tekrar düzenlenmesi ve özellikle olumlu sınıf ortamı ve atmosferi oluşturmada öğretmenlerle birlikte çalışılması gerekmektedir. Öğretmenlerin oyuna katılımları ve belirledikleri rollerle ilgili çalışmalar alanyazında mevcuttur (Aras, 2016; Güven ve Yıldız, 2014; Koçyiğit ve Başara Baydilek, 2015). Bu konuda hizmet öncesi ve hizmet içi eğitimlerle oyunun gelişimsel faydaları ve sınıf uygulama örneklerinin öğretmenlerle paylaşılmasının olumlu sonuçlar vereceği düşünülmektedir. Ayrıca Walsh v.d.'nin (2011) önerdiği oyun yapısının oyun ve ders arasındaki yapay farkın kalkmasında ve aralarındaki geçişkenliğin sağlanmasındave dolayısıyla olumlu atmosfer oluşturmada etkili olacağı düşünülmektedir.

Türkiye'de okulöncesinde okullaşma oranı hala çok gerilerdedir. 2015 verilerine göre 3-5 yaş arası çocukların ancak \%33.2'si herhangi bir okulöncesi eğitimi alarak okula başlamaktadır (MEB İstatistikleri, 2015-2016). Bu nedenle herhangi bir kurumsal eğitim deneyimi olmadan okula başlayan çocukların okula ısınma ve öğrenmeye olumlu yaklaşmaları için ilkokulların olumlu ortam sunmaları ayrıca önemlidir. Çocuk gelişimine uygun bir müfredat ve günlük akış mutlaka oyunu içine almalıdır. Ayrıca oyun yoluyla sosyal beceri gelişiminin sağlanması da çocukların okula uyumunu kolaylaştırıcı önemli bir etkendir. Bu nedenle işbirliği ve katılımcılığı arttıran oyun temelli deneyimlerin çocuklara sunulması bahsedilen iki durumun gerçekleşmesini sağlayacağı için önerilmektedir.

\section{Teşekkür}

Çalışmanın yürütülmesinde desteği ve katkısı olan il Milli Eğitim Müdürlüğüne, International Play Association ve Bernard Van Leer Foundation kuruluşlarına, Boğaziçi Üniversitesi Eğitim Fakültesi eski dekanı Sayın Prof. Dr. Güzver Yıldıran'a teşekkürlerimi sunarım.

\section{KAYNAKLAR}

Aras, S. (2016). Free play in early childhood education: a phenomenological study. Early Child Development and Care, 186(7), 1173-1184. Doi:10.1080/03004430.2015.1083558.

Ashiabi, G. S. (2007). Play in the preschool classroom: Its socioemotional significance and the teacher's role in play. Early Childhood Education Journal, 35, 199-207. Doi: 10.1007/s10643-007-0165-8.

Birleşmiş Milletler Çocuk Hakları Komitesi. (2013). General comment No. 17 on the right of the child to rest, leisure, play, recreational activities, cultural life and the arts (Article 31). http://www.refworld.org/docid/51ef9bcc4.htm (Erişim Tarihi: 2017, 04 Haziran).

Bredekamp, S. ve Copple, C. (Eds). (2000). Developmentally appropriate practice in early childhood programs. (Rev. ed.). Washington, DC: The National Association for the Education of Young Children (NAEYC).

Broadhead, P. (1997). Promoting sociability and cooperation in nursery settings. British Educational Research Journal, 23, 513-531. 
Broadhead, P. (2004). Early years play and learning: Developing social skills and cooperation. London: Routledge Falmer.

Bulunuz, M. (2012). Developing Turkish preservice preschool teachers' attitudes and understanding about teaching science through play. International Journal of Environmental \& Science, 7, 141-166.

Child Development Project. (1988-2005). Student Questionnaire: Child Development Project for Elementary School Students. Developmental Studies Center. http://www.devstu.org/sites/default/files/media/pdfs/cdp/DSC_ElemSch_scales.pdf

Durualp, E. ve Aral, N. (2010). Altı yaşındaki çocukların sosyal becerilerine oyun temelli sosyal beceri eğitiminin etkisinin incelenmesi. Hacettepe Üniversitesi Eğitim Fakültesi Dergisi, 39, 160-172.

Einarsdottir, J. (2014). Play and literacy: A collaborative action research project in preschool. Scandinavian Journal of Educational Research, 58(1), 93-109. Doi: 10.1080/00313831.2012.705321.

Elkind, D. (1981). The hurried child: growing up too fast too soon. Reading, Mass: AddisonWesley Pub. Co.

Elkind, D. (1987). Miseducation: Preschoolers at risk. New York: Knopf.

Elkind, D. (2007). The power of play: How spontaneous, imaginative activities lead to happier, healthier children. Cambridge, MA: Da Capo Lifelong.

Ginsburg, H. P. (2006). Mathematical play and playful mathematics: A guide for early education. D. Singer, R. M. Golinkoff ve K. Hirsh-Pasek (Ed.), Play=Learning: How play motivates and enhances children's cognitive and social-emotional growth içinde (s. 145-170). New York, NY: Oxford University Press.

Golly, A. ve Snead, C. (2004). Indicators of an orderly, positive and fully engaged classroom. Eugene, OR.

Gray, P. (2013). Free to learn: Why unleashing the instinct to play will make our children happier, more self-reliant, and better students for life. New York, NY: Basic Books.

Gülay Ogelman, H. (2014). Okul öncesi eğitim kurumlarında serbest zaman etkinliklerinin gözlemlenmesi. Mustafa Kemal Üniversitesi Sosyal Bilimler Enstitüsü Dergisi, 11(26), 125-138.

Güven, Ö. ve Yıldız, Ö. (2014). Sınıf öğretmenlerinin oyun ve fiziki etkinlikler dersinden beklentileri. Kastamonu Eğitim Dergisi, 22(2), 525-538.

Johnson, J., Christie, J. ve Wardle, F. (2005). Play, development and early education. Boston, MA: Pearson Education Inc.

Katz, L. (1988). Early childhood education: What research tells us. Bloomington, Ind: Phi Delta Kappa Educational Foundation.

Katz, L. (2015). Lively minds: Distinctions between academic versus intellectual goals for Young Children. Defending the Early Years Publications.

Koçyiğit, S. ve Başara Baydilek, N. (2015). Okul öncesi dönem çocuklarının oyun algılarının incelenmesi. YYÜ Eğitim Fakültesi Dergisi, 12(1),1-28.

MEB İstatistikleri (2015-2016). www.meb.gov.tr (Erişim Tarihi: 2017, 06 Haziran). 
Martlew, J., Stephen, C. ve Ellis, J. (2011). Play in the primary school classroom? The experience of teachers supporting children's learning through a new pedagogy. Early Years: An International Research Journal, 31(1), 71-83. Doi: 10.1080/09575146.2010.529425.

Miller, E. ve Almon, J. (2009). Crisis in the kindergarten: Why children need to play in school. Alliance for Childhood. http://www.allianceforchildhood.org/sites/allianceforchildhood.org/files/file/kinderga rten_report.pdf (Erişim Tarihi: 2017, 04 Haziran).

NAEYC. (1991). Guidelines for appropriate curriculum content and assessment in programs serving children ages 3 through 8 . Position statement of National Association for the Education of Young Children and the National Association of Early Childhood Specialists in State Departments of Education. Young Children, 46, 21-37.

Observational Checklists for Prosocial Behaviors of Elementary School Children. (n.d.). http://www.lionsquest.org/pdfs/ObservationalChecklistsForProsocialBehaviors.pdf (Erişim Tarihi: 2010, 06 Ocak).

Pramling Samuelsson, I. ve Johansson, E. (2006). Play and learning-inseparable dimensions in preschool practice, Early Child Development and Care, 176, 47-65.

Pellegrini, A. D. (2009). Research and policy on children's play. Child Development Perspectives, $3(2), 131-136$.

Sak, R., Şahin Sak, I. T. ve Tuncer, N. (2016). Turkish Preschool Children's Perceptions and Expectations Related to 1st-Grade Education. Childhood Education, 92(2), 149-154. Doi: 10.1080/00094056.2016.1150754.

Tuğrul, B., Metin Aslan Ö., Ertürk, H. G. ve Özen Altınkaynak, ş. (2014). Anaokuluna Devam Eden Altı Yaşındaki Çocuklar ile Okul Öncesi Öğretmenlerinin Oyun Hakkındaki Görüşlerinin İncelenmesi. Inönü Üniversitesi Eğitim Fakültesi Dergisi, 15(1), 97-116.

Varol, F. (2012). What they believe and what they do. European Early Childhood Education Research Journal, 21(4), 541-552. Doi:10.1080/1350293X.2012.677309.

Walsh, G., Sproule, L., McGuinness, C. ve Trew, K. (2011). Playful structure: a novel image of early years pedagogy for primary school classrooms. Early Years: An International Research Journal, 31(2), 107-119. Doi: 10.1080/09575146.2011.579070.

Whitebread, D. (2012). A report on the value of children's play with a series of policy recommendations. Toy Industries of Europe (TIE).

Wood, E. ve Attfield, J. (2005). Play, learning and the early childhood curriculum. (2.baskı) London: Paul Chapman.

Woolf, A. M. (2013). Social and emotional aspects of learning: Teaching and learning or playing and becoming. Pastoral Care in Education: An International Journal of Personal, Social and Emotional Development, 31(1), 28-42. Doi: 10.1080/02643944.2012.702782. 


\section{SUMMARY}

Expressing oneself in a variety of ways, building friendships, showing adaptive skills in a group, obeying rules are some skills and behaviors gained in early childhood. However, the design of classrooms, the curriculum and daily activities and routines were not based on the needs of early childhood. Introducing heavy academic content early might result in many deficits in development (Bredekamp ve Copple, 2000; Johnson, Christie, Wardle, 2005; NAEYC, 1991). Yet providing space for play in classroom will contribute to children's social skills such as conflict resolution, sharing, building friendships, acting together, showing empathy, and expressing and understanding emotions. Making play available throughout the day support children's cognitive skills as well. Some skills developed though play are: independent thinking, understanding other's intentions and thinking processes, problem solving, creative and imaginative skills, decision making, and self-monitoring (Ashiabi, 2007; Broadhead, 1997; Durualp ve Aral, 2010; Miller ve Almon, 2009; Woolf, 2012).

The aim of the study is to examine the effectiveness of a program titled 'Collaborative and Participatory Play-based Experiences' on classroom atmosphere, students' behaviors, students' school perceptions, and conflict resolution skills. The two main components of the program are: (a) provisions of the techniques of classroom management and understanding and guiding children's behaviors, (b) provisions of the games supporting social skills through participation and collaboration.

The program was implemented in fourteen primary schools' first grade classrooms. Twenty eight undergraduate students in early childhood education program applied the program for 10 weeks, 2 full days in a week. Seven masters' students of primary education program collected the pre and post test data. The in-class observations aiming to understand the general atmosphere of the classroom and student behaviors were made by using "Indicators of an orderly, positive and fully engaged classroom" (Golly \& Snead, 2004) and "Observational Checklists for Prosocial Behaviors of Elementary School Children" (n.d.). Perception of school and conflict resolution skills of the students were examined by using the interview protocols of "Child Development Project" (1988-2005). All the data was analyzed by doing frequency counts, computing percentiles, means and standard deviations. To compare pre and post test data, $t$ test analysis was used.

Although some improvements were observed in the general classroom atmosphere, statistically significant results were not found when pre and post test data was compared. When positive and negative student behaviors' pre and post test data was analyzed, the increase in the positive behaviors and the decrease in the negative behaviors were found. The increase was observed in conflict resolution and decision making behaviors, in a smaller degree in being sensitive, showing leadership skills, and encouraging others. A totally different tendency seemed to be the case when negative behaviors were considered. The decrease in all the negative behaviors were observed: selfishness, withdrawal, unresponsiveness, bossiness, rudeness, belittling, fighting/arguing, creation of conflict, avoidance of work, and carelessness.

For the perception of school variable, statistically significant results between pre and post test data were found. Enjoyment of in-class activities $(t(49)=2,796, p<.001)$; teacher's fairness $(t(49)=2,757$, $p<.05)$; and deciding on classroom rules together $(t(49)=2,289, p<.05)$. Contrary to the expectations, the scores dropped in a statistically significant manner in general self-esteem and in academic self-esteem. The result might have stemmed from the high expectations of accomplishments in acquisition of reading and writing skills towards the end of the academic year. In terms of conflict resolution skills, the scores of aggression and withdrawal behaviors decreased while the scores of negotiation and adultdependency increased.

The study's aim was to examine the effectiveness of a program striving to develop a positive environment for children through participatory and collaborative games. The results showed some significant outcomes even though the application of the program was comparatively short. The suggestion is to provide such environments to children by ensuring the continuance and persistence of positive atmosphere. It is hoped that the positive outcomes of this study could shed light on the future studies that are aimed to provide play-based experiences for children improving collaboration and participation at schools. 